\title{
Full-fit reconstruction of the Labrador Sea and Baffin Bay
}

\author{
M. Hosseinpour ${ }^{1}$, R. D. Müller ${ }^{1}$, S. E. Williams ${ }^{1}$, and J. M. Whittaker ${ }^{2}$ \\ ${ }^{1}$ EarthByte Group, School of Geosciences, University of Sydney, Sydney, NSW 2006, Australia \\ ${ }^{2}$ Institute for Marine and Antarctic Studies, University of Tasmania, Hobart, TAS 7005, Australia \\ Correspondence to: M. Hosseinpour (maral.hosseinpour@sydney.edu.au)
}

Received: 7 June 2013 - Published in Solid Earth Discuss.: 8 July 2013

Revised: 25 September 2013 - Accepted: 3 October 2013 - Published: 26 November 2013

\begin{abstract}
Reconstructing the opening of the Labrador Sea and Baffin Bay between Greenland and North America remains controversial. Recent seismic data suggest that magnetic lineations along the margins of the Labrador Sea, originally interpreted as seafloor spreading anomalies, may lie within the crust of the continent-ocean transition. These data also suggest a more seaward extent of continental crust within the Greenland margin near Davis Strait than assumed in previous full-fit reconstructions. Our study focuses on reconstructing the full-fit configuration of Greenland and North America using an approach that considers continental deformation in a quantitative manner. We use gravity inversion to map crustal thickness across the conjugate margins, and assimilate observations from available seismic profiles and potential field data to constrain the likely extent of different crustal types. We derive end-member continental margin restorations following alternative interpretations of published seismic profiles. The boundaries between continental and oceanic crust (COB) are restored to their pre-stretching locations along small circle motion paths across the region of Cretaceous extension. Restored COBs are fitted quantitatively to compute alternative total-fit reconstructions. A preferred full-fit model is chosen based on the strongest compatibility with geological and geophysical data. Our preferred model suggests that (i) the COB lies oceanward of magnetic lineations interpreted as magnetic anomaly 31 (70 Ma) in the Labrador Sea, (ii) all previously identified magnetic lineations landward of anomaly 27 reflect intrusions into continental crust and (iii) the Ungava fault zone in Davis Strait acted as a leaky transform fault during rifting. This robust plate reconstruction reduces gaps and overlaps in Davis Strait and suggests that there is no need for alternative models proposed for reconstructions of this area including additional plate boundaries in North America or Greenland.
\end{abstract}

Our favoured model implies that break-up and formation of continent-ocean transition (COT) first started in the southern Labrador Sea and Davis Strait around $88 \mathrm{Ma}$ and then propagated north and southwards up to the onset of real seafloor spreading at $63 \mathrm{Ma}$ in the Labrador Sea. In Baffin Bay, continental stretching lasted longer and actual break-up and seafloor spreading started around $61 \mathrm{Ma}$ (chron 26).

\section{Introduction}

The Labrador Sea and Baffin Bay formed following Cretaceous rifting between Greenland and North America (Fig. 1). The relative motions between these two plates in the Palaeocene following the onset of seafloor spreading can be reconstructed based on the identification of seafloor spreading magnetic anomalies (Roest and Srivastava, 1989; Oakey and Chalmers, 2012). Reconstructing the relative motions of the Greenland and North American plates for times prior to seafloor spreading depends on accurately identifying the present-day extent of stretched continental crust along the conjugate margins and undoing this extension in the reconstruction. Uncertainties in the distribution of crustal types and identification of seafloor spreading anomalies have implications for plate tectonic reconstructions, in particular for the rifting and early seafloor spreading phases. Existing reconstruction models for the relative positions of Greenland and North America during Cretaceous continental rifting include those of Bullard et al. (1965), Rowley and Lottes (1988), Srivastava and Roest (1989) and Dunbar and Sawyer (1989) These reconstructions were derived under assumptions that much of the crust in the continent-ocean transition (COT) was oceanic during chron 28-31 time (70-64 Ma according to timescale from Gradstein et al., 2012) and that 
spreading anomalies could be used to constrain relative plate motions (Roest and Srivastava, 1989). This appears questionable in the light of subsequently collected seismic data, yet the anomaly identifications and reconstructions derived from these interpretations are still used within global-scale compilations (Torsvik et al., 2008; Müller et al., 2008; Seton et al., 2012). More recent reconstruction models only consider seafloor spreading since chron 27 (63 Ma), the earliest undebated spreading anomalies (Oakey, 2005; Oakey and Chalmers, 2012).

In this paper we investigate the full-fit configuration of Greenland and North America in the light of available geophysical and geological data. The distribution of crustal types in the margins of Labrador Sea and Baffin Bay were determined using interpreted seismic lines and other geophysical data to extract the limits of continental deformation. A map of crustal thickness was derived by inversion of gravity data constrained by Moho depth estimates from seismic refraction profiles and receiver functions. Next, the extended continental crust within the conjugate margins was restored to determine the pre-rift extent of each plate. These boundaries are used as quantitative constraints in generating new poles of rotation for the full-fit configuration of North America and Greenland. We show that previous reconstructions overestimate the amount of closure between the two plates. Our new reconstruction, incorporating more recent evidence of the extent of continental crust, reduces the gaps in the Labrador Sea and overlaps in Davis Strait and Baffin Bay which occurred in previous reconstructions of this region.

\section{Regional tectonic models}

Several authors have presented poles of rotations that describe the relative motions of Greenland and North America between the onset of Mesozoic rifting and cessation of seafloor spreading at chron 13 time (34 Ma). Rowley and Lottes (1988) generated stage poles of rotation of Greenland relative to North America in the context of reconstruction of the North Atlantic and Arctic. This reconstruction took into account both onshore geology and offshore geological and geophysical data including magnetic anomalies, fracture zones and syn-rift extension data. Dunbar and Sawyer (1989) created another full-fit reconstruction for the central and North Atlantic including the Labrador Sea with a methodology similar to this study as it treats the continents as non-rigid in the rifting phase. They estimate continental extension from total tectonic subsidence rates of margins and seismic studies and restored the continent-ocean boundaries (COB)s to their pre-rift configurations. Roest and Srivastava (1989) and Srivastava and Roest (1999) introduced poles of rotation from the break-up stage $(118 \mathrm{Ma})$ up to the end of seafloor spreading (34 Ma) in the Labrador Sea based on new interpretation of linear magnetic anomalies, gravity data and fracture zones in this area.

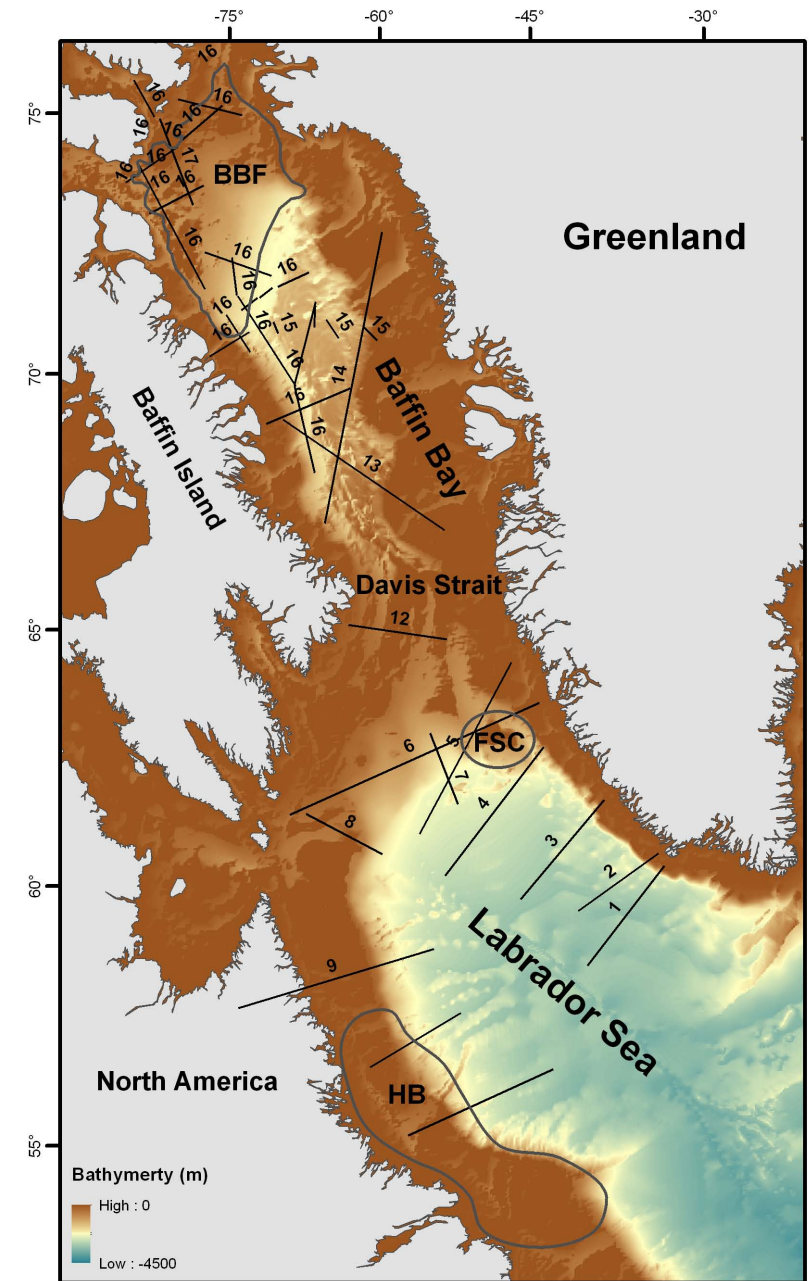

Fig. 1. Bathymetry of the Labrador Sea, Davis Strait and Baffin Bay (Louden et al., 2004). The seismic refraction and reflection lines discussed in this paper are shown as thick black lines 1: Chalmers (1997) line BGR77-17; 2: Chian and Louden (1994) line88R2; 3: Chalmers (1997) line BGR77-21; 4: Chalmers (1997) line BGR77-12; 5: Chalmers (1997) line BGR77-6; 6: Funck et al. (2007) Nugget line 1; 7: Gerlings et al. (2009) NUGGET line2; 8: Keen et al. (2012) line TGS1; 9: Keen et al. (2012) Profile1 (Gravity Profile); 10: Keen et al. (2012) line TGS3; 11: Chian et al. (1995a) line90R1; 12: Suckro et al. (2013) line AWI-20080700; 13: Funck et al. (2012) line AWI-20080600; 14: Suckro et al. (2012) composite line consisting of AWI-20080500 and AWI-20100400; 15: Keen and Barret (1972); 16: Harrison et al. (2011); 17: Harrison et al. (2011); line3c and Reid and Jackson (1997) line 4. BBF: Baffin Bay Fan; FSC: Fylla Structural Complex; HB: Hopedale Basin.

A more recent reconstruction for the opening of the Labrador Sea and Baffin Bay was presented in Oakey (2005) and Oakey and Chalmers (2012), who combined Roest and Srivastava (1989) magnetic anomaly picks for chrons 27 to 13 (63 to $34 \mathrm{Ma}$ ) from the Labrador Sea with new picks from Baffin Bay. They presented new poles of rotation for the $24 \mathrm{R}$ 
interval, which correlates with the start of seafloor spreading between eastern Greenland and Europe, but no new poles for the earlier rifting. Significantly, these studies do not use spreading anomalies for chrons older than chron 27 on the grounds that these anomalies, used in the reconstructions of earlier authors, were located within the COT and are not true spreading isochrons. This debate is important both for reconstructions of the early seafloor spreading and for delineating and restoring the extended continental crust within each margin, and is discussed further in the next section

\section{Tectonic setting}

Rifting and the extension of the Labrador Sea started either in the late Jurassic (160 Ma) based on dating of coastparallel dykes in SW Greenland or the early Cretaceous (140 Ma), on the basis of distinguishing and dating syn-rift sediments from wells on both margins (Chain and Louden, 1994). These sediments were deposited on top of rift-related volcanics in grabens and half-grabens that formed during continental extension (Srivastava and Roest, 1999; Chalmers and Pulvertaft, 2001). Seafloor spreading in the Labrador Sea started along a branch of the mid-Atlantic in either the late Cretaceous or early Palaeocene times (Roest and Srivastava, 1989; Keen et al., 1993; Srivastava and Roest, 1999; Chian et al., 1995a; Chalmers and Laursen, 1995; Chalmers and Pulvertaft, 2001; Keen et al., 2012) and ceased about $35 \mathrm{Ma}$ (chron 13), leaving an extinct spreading centre in the middle of the basin. The existence of oceanic crust in Baffin Bay was first shown in seismic refraction lines. Magnetic anomalies along these lines were determined in two different directions - NNW-SSE and NW-SE - in this area. These lineations were interpreted as Palaeocene and Eocene extinct spreading ridges (Keen and Barrett, 1972; Keen et al., 1974; Chalmers and Pulvertaft, 2001; Oakey, 2005).

The age of the earliest seafloor spreading magnetic anomalies within the Labrador Sea is controversial. The uncertainty originates from differing interpretations of the nature of crust within the COT between unequivocal continental and oceanic crust in both margins. Roest and Srivastava (1989) interpreted this zone as oceanic crust containing linear magnetic anomalies 31-33 formed during slow seafloor spreading (Fig. 2). Other authors interpreted this crust as exhumed and serpentinised mantle or high-velocity igneous crust overlain by thin oceanic basalts, highly fractured and hydrothermally altered (Chian and Louden, 1994; Lundin and Dore, 2011; Keen et al., 2012). Some other studies (Chian and Louden, 1994, Chian et al., 1995a, b; Reston, 2009; Dickie et al., 2011) conclude that seafloor spreading starts sometimes between chron 31 and chron 27 . This interpretation is based on data derived from seismic lines, subsidence history and stratigraphic characteristics of both margins. Nonetheless, Chalmers (1991), Chalmers and Laursen (1995), Chalmers and Pulvertaft (2001) and Funck et al. (2007) interpreted

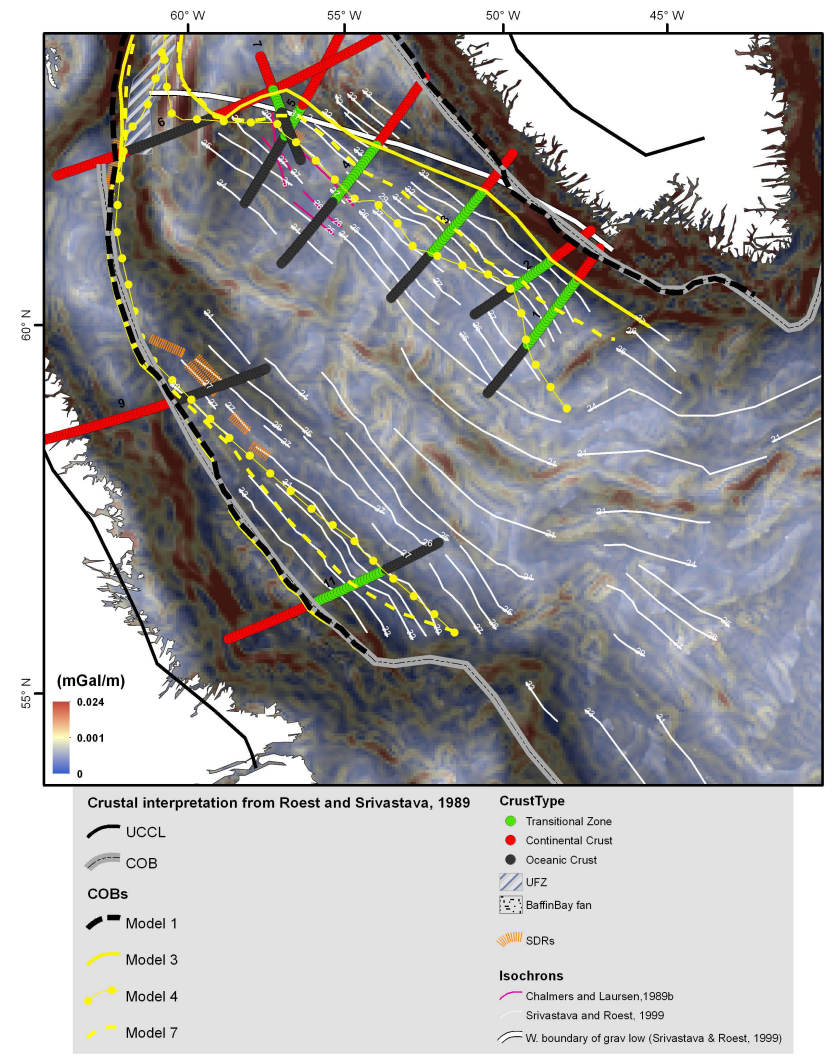

Fig. 2. Interpreted crustal structure and alternative COB models in the Labrador Sea shown overlying Bouguer gravity (derived from EGM08). UCCL (black) line is the same for all models. Four alternative COB interpretations are shown: model 1 (dashed black line) is based on Roest and Srivastava (1989) crustal interpretation, model 3 (continuous thick yellow line) is the most landward COB (same as model 2 in the Labrador Sea), model 4 (yellow line with circles) is the most oceanward COB (same as model 5 in the Labrador Sea) and Model 7 (dashed yellow line) interprets the $\mathrm{COB}$ within the range of the transitional zone (same as model 6 in the Labrador Sea). The numbering for seismic lines is the same as Fig. 1

these anomalies as being a result of magmatic intrusion into highly thinned and stretched continental crust based on interpretation of reflection seismic profiles and that the oldest true seafloor spreading anomaly is chron 27 (Fig. 2).

The nature of the crust within Davis Strait is also debated. Chalmers and Pulvertaft (2001) describe the entire crust in Davis Strait as continental, while Srivastava (1983) described sedimentary basins flanking Davis Strait High as oceanic, whereas they stated that the nature of the crust in the basement high of Davis Strait could be described as continental.

Several studies (Funck et al., 2007, 2012; Keen et al., 2012; Suckro et al., 2013) propose that the Ungava Fault Zone (UFZ) in Davis Strait acted as a leaky transform fault (Fig. 3) and this extensional phase thinned the continental crust, allowing melted material from the proto-Iceland plume 


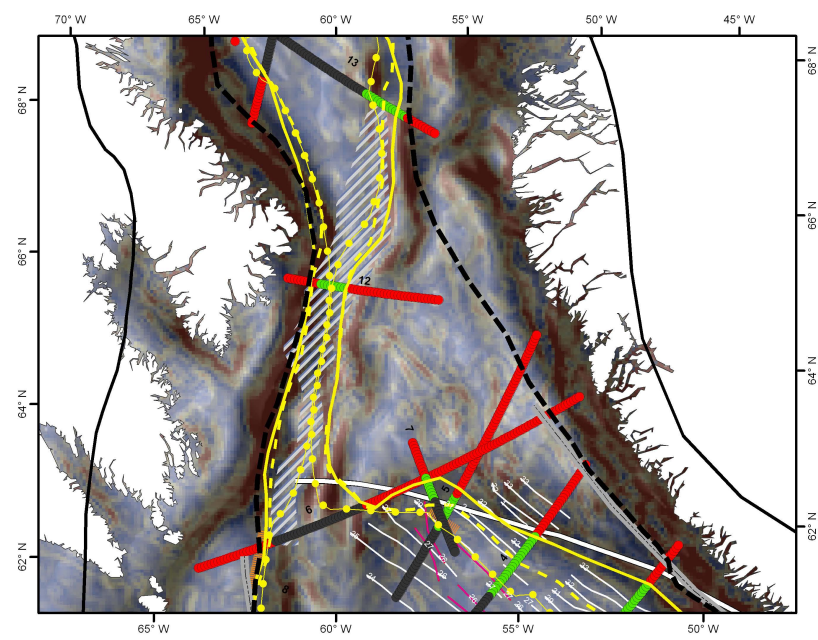

Fig. 3. Interpreted crustal structure and alternative COB models in Davis Strait. Key is the same as for Fig. 2.

to penetrate and fill it as new oceanic crust (Storey et al., 1998; Funck et al., 2007) or as a mixture of continental crust and plume related material (Keen and Barrett, 1972).

The Oakey and Chalmers (2012) reconstruction of chron 27-25 suggests a Palaeocene extensional phase along the UFZ continued as a transpressional tectonic regime during the Eocene. In their model, this structural inversion leads to the formation of the Davis Strait High, a structural feature that resulted from over-thrusting of Precambrian and Ordovician continental units onto Palaeogene volcanic rocks.

Uncertainty in the extent of continental crust and nature of the COT continues northward of Davis Strait in southern Baffin Bay mostly on the Greenland margin. Funck et al. (2012) interpret a northward extension of the UFZ as a continuation of the leaky transform fault. Remnants of continental crust or a transform fault associated with UFZ lay between this zone and normal oceanic crust of Baffin Bay (Chalmers and Pulvertaft, 2001; Funck et al., 2012). Another interpretation defines this zone as Palaeocene oceanic crust (Oakey and Chalmers, 2012; Funck et al., 2012; Suckro et al., 2012). In comparison, along the Baffin Island margin the continent-ocean boundary is much sharper, recognisable by a strong positive gravity high all along the margin (Fig. 4).

Both margins in the northernmost area of Baffin Bay have been interpreted as non-volcanic with basement highs and faulted continental crust, a rough basement of exhumed and serpentinised mantle and submarine basalts within the interpreted COT, and smoother oceanic crust with only weak magnetic anomalies (Whittaker et al., 1997; Skaarup et al., 2006). Oceanic crust terminates in northern Baffin Bay at about $76^{\circ} \mathrm{N}$ (Reid and Jackson, 1997; Oakey and Stephenson, 2008).

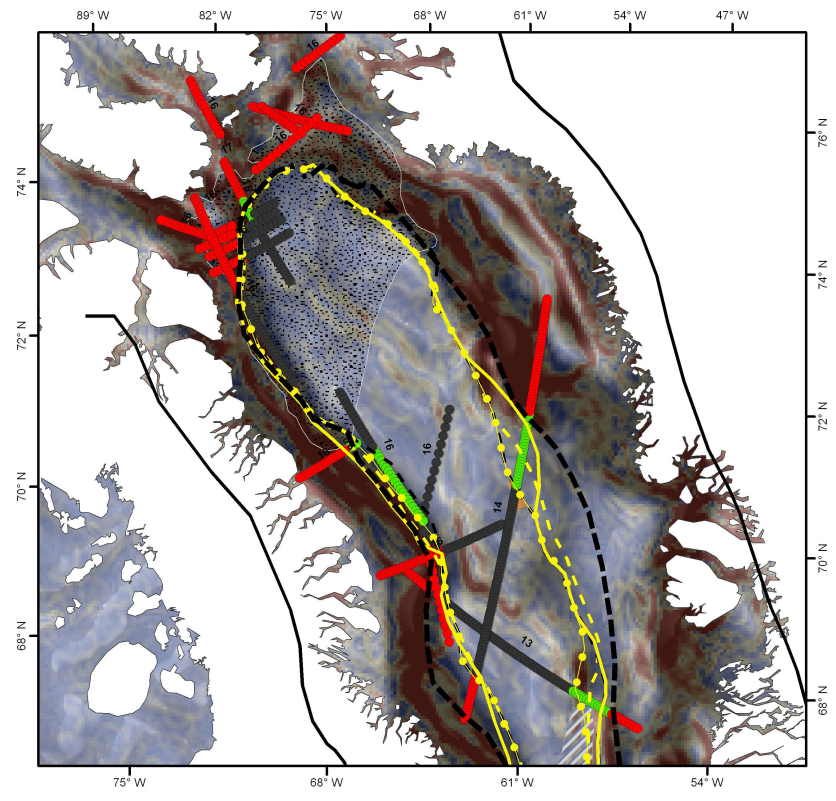

Fig. 4. Interpreted crustal structure and alternative $\mathrm{COB}$ models in Baffin Bay. Key is the same as for Fig. 2.

\section{Methodology}

\subsection{Delineation of crustal types across the COT}

The distribution of crustal types and the nature of the COT within the study area remain poorly constrained. For this reason, we investigate end-member cases for the extent of continental crust within the COT for each margin based on available seismic profiles, using a simple classification scheme similar to the approach of Crosby et al. (2011) (Fig. 5). We mapped the most landward position of "certain" oceanic crust and the most oceanward position of "certain" stretched continental crust. Determining these two boundaries relies upon interpretations of the crustal nature in seismic profiles along both margins in different studies. This interpretation is mainly based on changes in $P$ wave velocity, crustal thickness, observation of detachment faults and seaward dipping reflectors (SDRs), along with information obtained from exploration wells wherever they exist. The nature of the intervening crust is open to interpretation. Importantly for our reconstructions, it is unclear how much of the material mapped within the present-day crust within these zones was part of the crust before the rifting, and how much was added, for example due to igneous intrusion or mantle exhumation. The crust underneath Davis Strait has been considered alternatively as completely continental (Chalmers and Pulvertaft, 2001; Gerlings et al., 2009) or mostly continental with a narrow strip of Palaeocene oceanic crust in the southwestern boundary of Davis Strait High that could be the result of a Palaeocene extensional phase (Funck et al., 2007, 2012; 


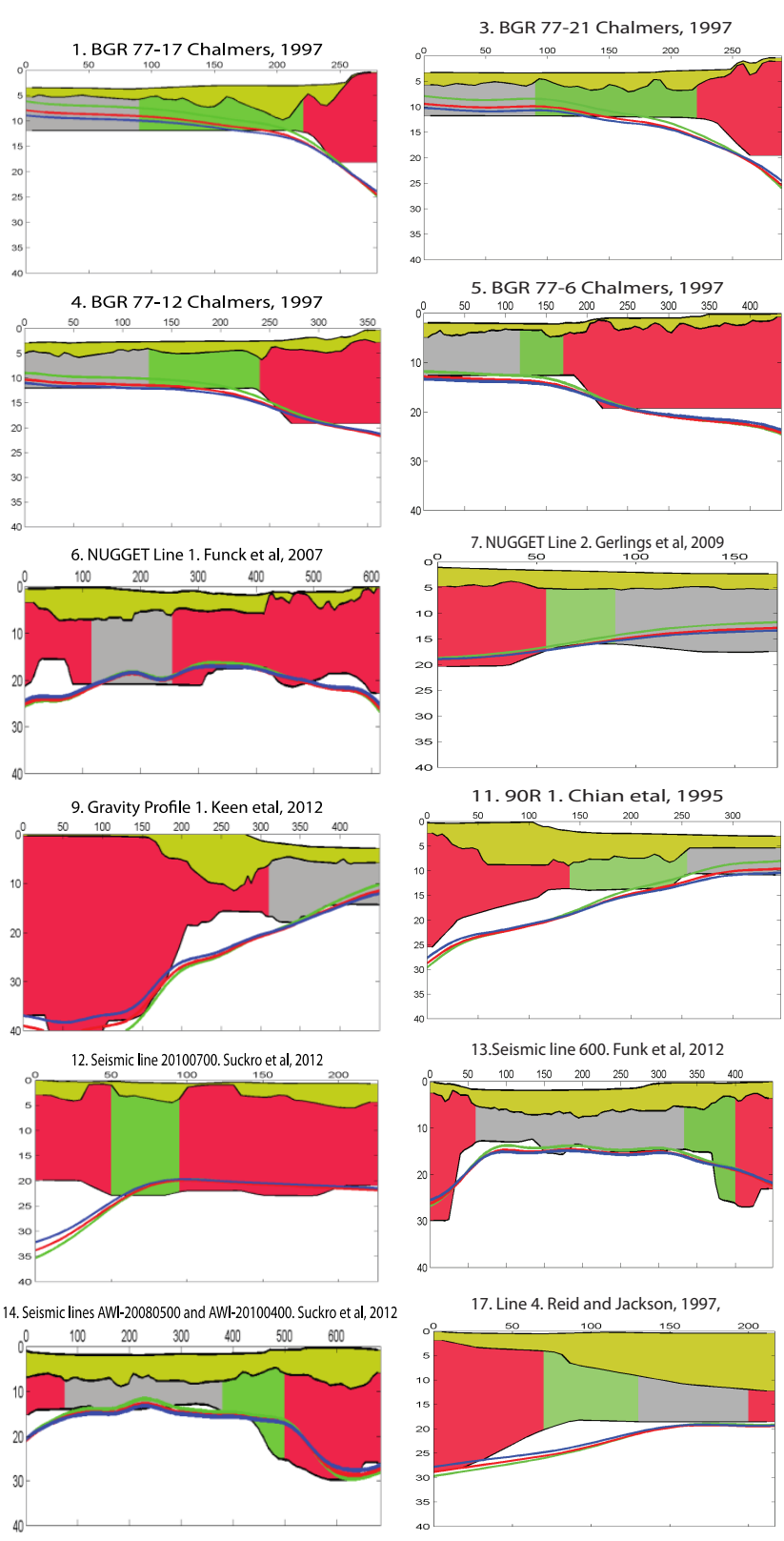

Fig. 5. Seismic profiles showing crustal type interpreted from different studies, locations shown in Figs. 1 to 4. Red - continental crust; green - transitional crust; grey - oceanic crust; yellow - sediments. Coloured lines show crustal thickness computed using gravity inversion: blue for initial crustal thickness of $37 \mathrm{~km}$ and density of $500 \mathrm{~kg} \mathrm{~m}^{-3}$, red for initial crustal thickness of $38 \mathrm{~km}$ and density of $450 \mathrm{~kg} \mathrm{~m}^{-3}$, and green for initial crustal thickness of $40 \mathrm{~km}$ and density of $400 \mathrm{~kg} \mathrm{~m}^{-3}$.

Keen et al., 2012; Oakey and Chalmers, 2012; Suckro et al., 2013).

We generated alternative plate reconstructions using the end-member scenarios for the COT, allowing us to investigate the effect of uncertainty in the extent of continental crust on the full-fit reconstruction between Greenland and North
America. These different models can be summarised as follows:

1. An extremely landward COB based on the definition of Srivastava and Roest (1989). This model assumes that the COB lies at the edge of the continental shelf along the Greenland margin. The position of this boundary is less clear on the Labrador margin because thinned and extended continental crust is wider here (Srivastava and Roest, 1999). Further north, through Davis Strait, a more landward COB implies oceanic crust for the area and follows the continental shelf in both Greenland and Baffin Island margins.

2. The most landward COB (within the limits of current seismic interpretations). The $\mathrm{COB}$ is located at the landward limit of the COT and assumes that the entire Davis Strait underlain with continental crust.

3. The same as (2) in the Labrador Sea and Baffin Bay but assumes the existence of a narrow strip of oceanic crust described as Ungava leaky transform fault passing through the western edge of the Davis Strait High.

4. The most oceanward $\mathrm{COB}$ (within the limits of current seismic interpretations). The oceanward boundary of the COT was taken as the COB in the Labrador Sea and Baffin Bay. This model assumes the presence of continental crust across the entire Davis Strait.

5. The same as (4) but assuming the UFZ is a leaky transform fault and that Davis Strait contains oceanic crust.

6. The COB falls within the COT permitted by seismic reflection data. In the Labrador Sea the COB is located landward of chron 31 (70 Ma) assuming this isochron as the first seafloor spreading anomaly in this region. This model is based on the assumption that Davis Strait is continental.

7. The same as (6) but with narrow strip of ocean crust in Davis Strait.

\subsection{Generating the crustal thickness grid}

We derived a map of crustal thickness for the Labrador Sea and Baffin Bay. This grid enables us to distinguish the unstretched continental crust boundary (UCCL) where the continental crust starts thinning at the onset of rifting, and thus with recognising this limit it is possible to restore the COB to its pre-rift location. Generating the crustal thickness grid has been performed by inversion of gravity data using the method of Chappell and Kusznir (2008). The starting point for this method is the global free-air gravity anomaly compilation of Sandwell and Smith (2009). We estimated the gravity effects of bathymetry (Divins, 2004) (Fig. 6a) and sediment layers (Louden et al., 2004; Divins, 2003; Bassin et al., 


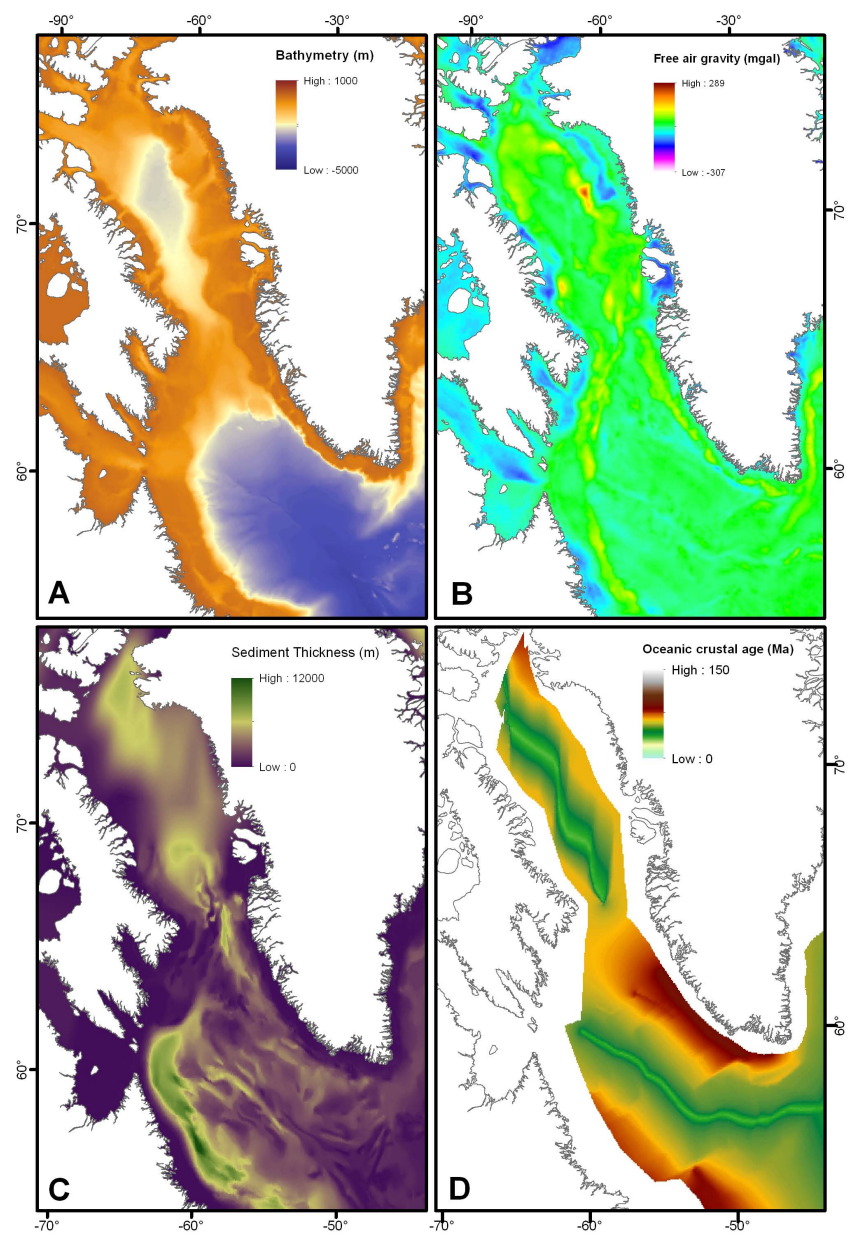

Fig. 6. Grids used to generate crustal thickness maps based on the gravity inversion method of Chappell and Kusznir (2008). (A) Bathymetry (Louden et al., 2004) (B) free-air gravity (Sandwell and Smith, 2009) (C) sediment thickness (Louden et al., 2004; Divins, 2003; Bassin et al., 2000). (D) Age grid modified from Müller et al. (2008).

2000; Fig. 6c) and subtracted these from the observed free-air gravity. The gravity effect of mantle thermal variations was estimated on the basis of seafloor age (Müller et al., 2008; Fig. 6d). The need to correct for mantle density variations is supported by the 2-D gravity model of Keen et al (2012), who showed that a lower mantle density was necessary beneath the Labrador Sea compared to the flanking continents in order to match gravity and seismic observations. The remaining gravity signal is inverted using the method of Parker (1972) to derive a map of depth to the Moho (Fig. 7). A complete description of the workflow is provided in Appendix A. Crustal density, initial crustal thickness and the seafloor age grid influence the results of this method, so we performed sensitivity tests to investigate the influence of these parameters on the resulting crustal thickness and chose the combination of a reference crustal thickness of $37 \mathrm{~km}$ and a density contrast across the Moho of $500 \mathrm{~kg} \mathrm{~m}^{-3}$ that results in

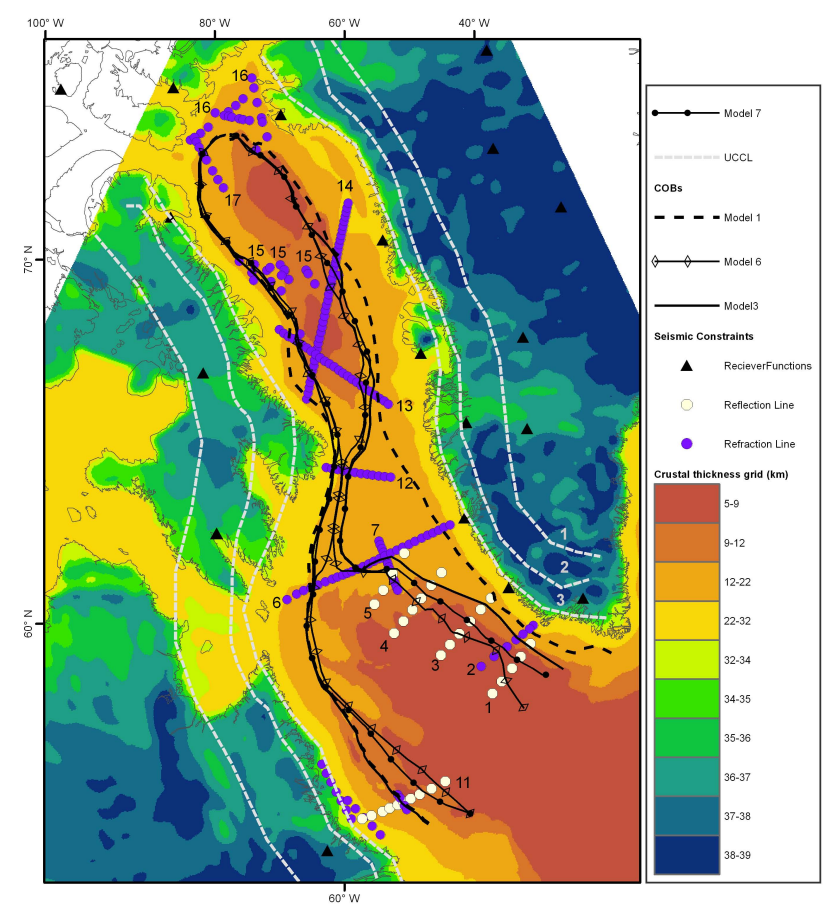

Fig. 7. Crustal thickness grid computed using the gravity inversion method. We defined three sets of UCCL for conjugate margins to examine the effect of changing the unstretched crust limit of restored COBs. UCCL number 1 is the most inland limit and corresponds to the crustal thickness $\sim 40 \mathrm{~km}$. Numbers 2 and 3 represent the limit of $\sim 37$ and $\sim 34 \mathrm{~km}$ respectively. The seismic line numbers are the same as Fig. 1. Receiver functions on Greenland are from Dahl-Jensen et al. (2003). The North American receiver functions derived from Darbyshire (2003) and Ramesh et al. (2002).

the lowest RMS to produce the crustal thickness grid. These sensitivity tests are discussed in detail in Appendix A and Fig. A1.

We investigated the possibility that our crustal thickness grids in Davis Strait and southern Baffin Bay included igneous material added to the continental crust during the passage of the proto-Icelandic plume beneath this area around $70 \mathrm{Ma}$ (Lawver and Müller, 1994). Such igneous material has been reported along seismic lines AWI-20080600 (Funck et al., 2012), AWI-20100700 (Suckro et al., 2013), NUGGET line 1 (Funck et al., 2007) and NUGGET line 2 (Gerlings et al., 2009) and WA Line (Gohl and Smithson, 1993), where high-velocity lower crust is reported. The thickness of interpreted igneous crust reaches $9 \mathrm{~km}$. The igneous activity associated with the passage of the Iceland plume has a Palaeocene age (70-57 Ma) (Storey et al., 1998) and hence postdates the rifting period. Our reconstruction methodology relies on restoring the volume of continental crust that existed before rifting, so it is important to consider the potential error introduced by using crustal thickness grids that include a significant volume of material added during or after rifting. 
For this step in our workflow we defined a region with a high likelihood of being affected by the addition of late Cretaceous-Tertiary igneous material. The zone spans the northern Labrador Sea and Davis Strait and extends northward to the southern Baffin Bay and Disko Island region (Fig. 8). Constraints on the distribution and thickness of the igneous crust come from the seismic lines mentioned above. Where no seismic data are available, especially on the Greenland margin near Disko Island from 67 to $72^{\circ} \mathrm{N}$, we use the western Greenland/Baffin Island Tertiary volcanic distribution maps of Chalmers and Pulvertaft (2001) and Skaarup et al. (2006). The thickness of volcanic addition in these offshore regions is poorly constrained, but the total extrusive sequence onshore varies from 3 to $5 \mathrm{~km}$ around Disko Island, with $2 \mathrm{~km}$ suggested as a minimum estimate for the average thickness across the onshore and offshore regions (Storey et al., 1998). The considerable thickness of extrusives suggests that an equivalent or greater thickness of intrusive volcanic bodies in the lower crust could also be present (White et al., 2008). In this study we assumed a thickness of igneous material up to $4 \mathrm{~km}$ across the areas not constrained by seismic profiles. The estimated thickness of igneous additions to the stretched continental crust was subtracted from the crustal thickness grid, and the restoration of COBs repeated with the corrected crustal thickness grid.

The resulting crustal thickness grid (Fig. 7) shows that continental crustal thickness varies from around $40 \mathrm{~km}$ for inland cratons of North America and Greenland to less than $9 \mathrm{~km}$ under extremely thinned and stretched continental crust adjacent to both margins. Figure 9 illustrates the comparison between Moho depths from seismic experiments and the Moho depth extracted from gravity inversion along each of the seismic profiles being used in this study (Fig. 1). We also compare our database of seismic refraction (violet circles in Fig. 7) and receiver function (black triangles in Fig. 7) depths (Jackson and Reid, 1994; Hall et al., 2002; Ramesh et al., 2002; Darbyshire, 2003; Dahl-Jensen et al., 2003) with the Moho depth contained within the CRUST2 model of global crustal structure (Bassin et al., 2000). The comparison shows that the global grid gives typically deeper Moho compared with individual seismic profiles and suggests that the gravity inversion method will yield more robust crustal thickness restoration.

A lithospheric thinning factor $(\gamma)$ grid illustrates the implications for crustal stretching of our crustal thickness grid. The parameter $\gamma$ is derived from the lithospheric stretching factor beta $(\beta)$ and taking into account the addition of igneous material added to the crust during rifting:

$\beta=\operatorname{tc} 0 / \mathrm{tc} 1$,

where tc0 is the initial unstretched continental crustal thickness used to produce the crustal thickness grid and tc1 is the crustal thickness at present day.

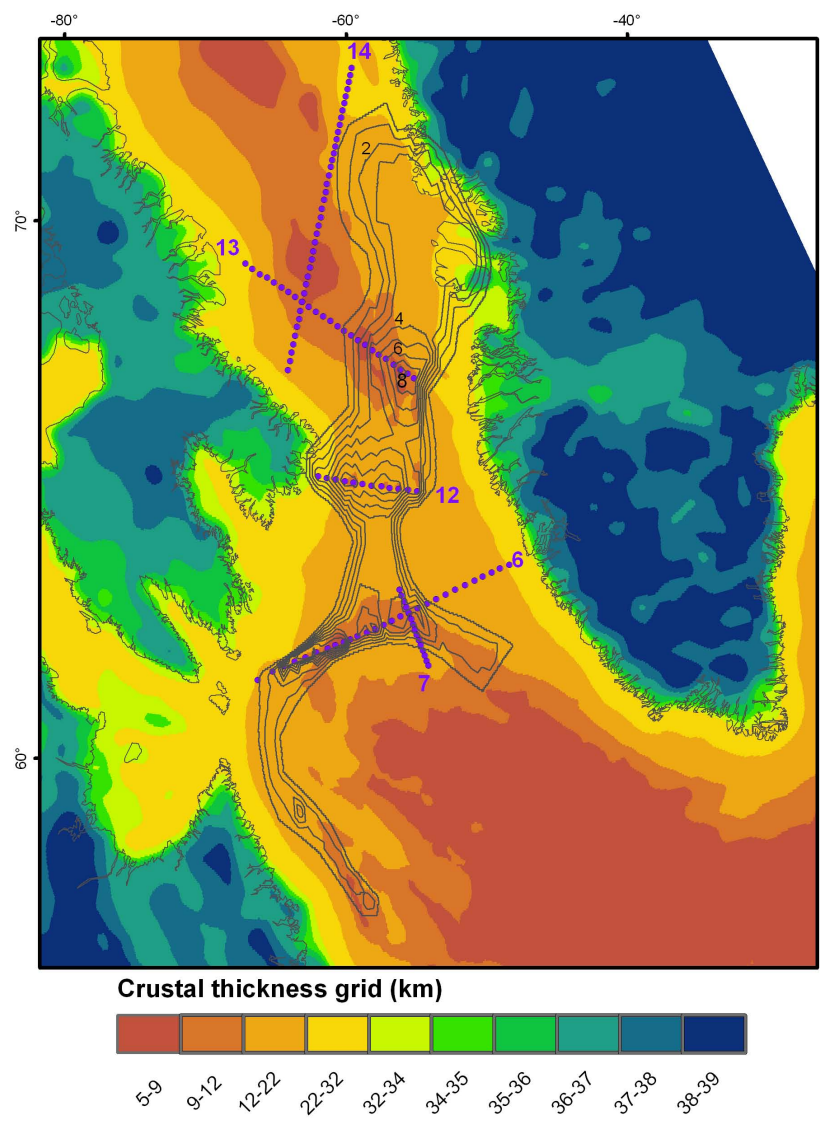

Fig. 8. The crustal thickness grid after elimination of igneous layers Thin grey contour lines show the extent and the amount of igneous crust in $\mathrm{km}$. Seismic data that has been used in determining the amount and distribution of igneous material have been shown in violet circles. The seismic line numbers are the same as Fig. 1 .

The gamma factor $\gamma$ is calculated using

$\gamma=(1-1 / \beta)$

This factor is sensitive to the addition of igneous material to the crust as magmatic underplating and/or oceanic crust and thus is useful for showing the extent of thinned crust along rifted margins. Gamma varies from 0.5 for volcanic margins to 0.7 for normal and magma-poor margins (Kuzsnir, 2009). Figure 10 shows the thinning factor grid for the entire study region overlain by COB lines for our preferred model. In the magma-starved south Labrador Sea, COBs follow the 0.7 gamma contour, while it changes to 0.6 in the northern parts, where rifting was accompanied by excess magmatism. In Davis Strait the gamma grid shows a relatively thick crust with a thinning factor around $0.4-0.5$. This over-thickened crust may reflect igneous crust or underplating in this area. Along the southern Baffin Bay volcanic margins, COBs correspond to gamma factors of 0.6 to 0.7 on both margins. A $92000 \mathrm{~km}^{2}$ submarine fan complex referred to as the Baffin Fan covers most of this area (Fig. 10) (Harrison et al., 2011). 


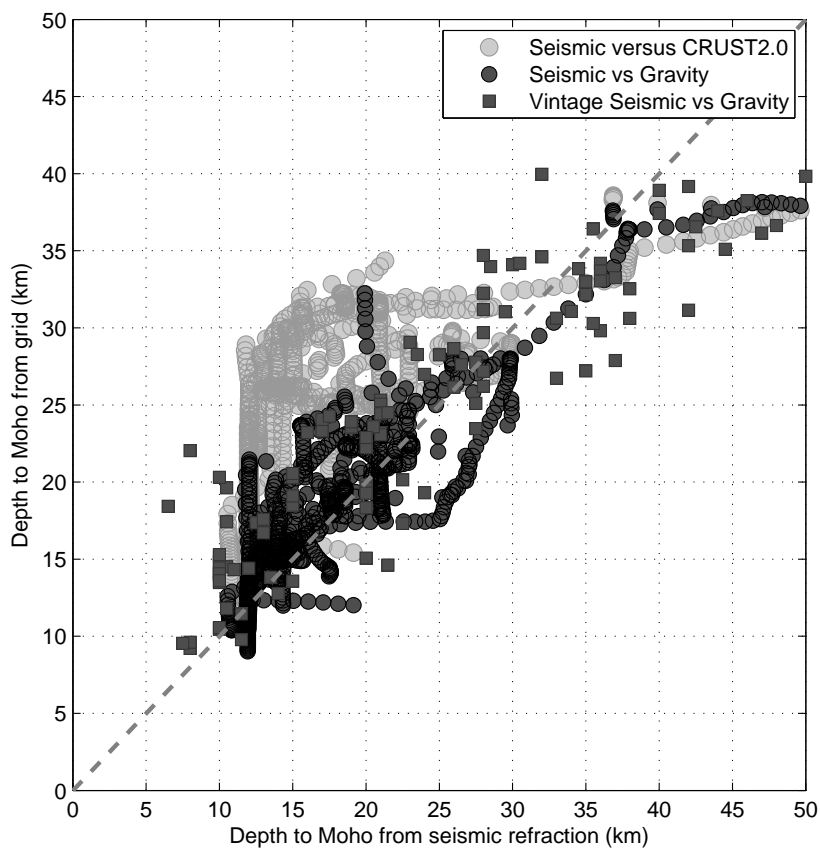

Fig. 9. Comparison of depth to Moho between independent seismic interpretations presented in Fig. 1, a global crustal thickness map (CRUST2 model) (Bassin et al., 2000) and our computed crustal thickness from gravity inversion. Dark-grey circles show seismic depths versus gravity-inversion-derived Moho depths. Squares show the Moho depths from pre-2000 seismic studies versus gravity depth. Light-grey circles show seismic depths versus CRUST2 model depths. Depths from CRUST2 model are typically deeper compared to regional seismic data. The grey dashed line is a $1: 1$ trend.

This massive volume of sedimentary cover makes the gravity data unable to detect basin slope topography, which leads to greater uncertainty in computed crustal thickness in this region. Defining COBs in this area mainly relies on seismic profiles.

\subsection{Restoring extended crust between UCCL and COB boundaries}

For each model, the extended continental crust between the COB and UCCL was restored along each margin to an unstretched thickness. The UCCL has been placed to where the crust starts thinning and the crustal thickness grid was used to derive this limit (Fig. 7). However, we used seismic profiles and teleseismic data analysed via receiver functions in both North America (Hall et al., 2002; Ramesh et al., 2002; Darbyshire, 2003) and Greenland (Gohl and Smithson, 1993; Jackson and Reid, 1994; Dahl-Jensen et al., 2003) together with gravity-inversion-derived crustal thicknesses on the Greenland side (Braun et al., 2007; Welford and Hall, 2013) to further double-check and reinforce our interpreted UCCL location. Previous studies suggest that the unstretched

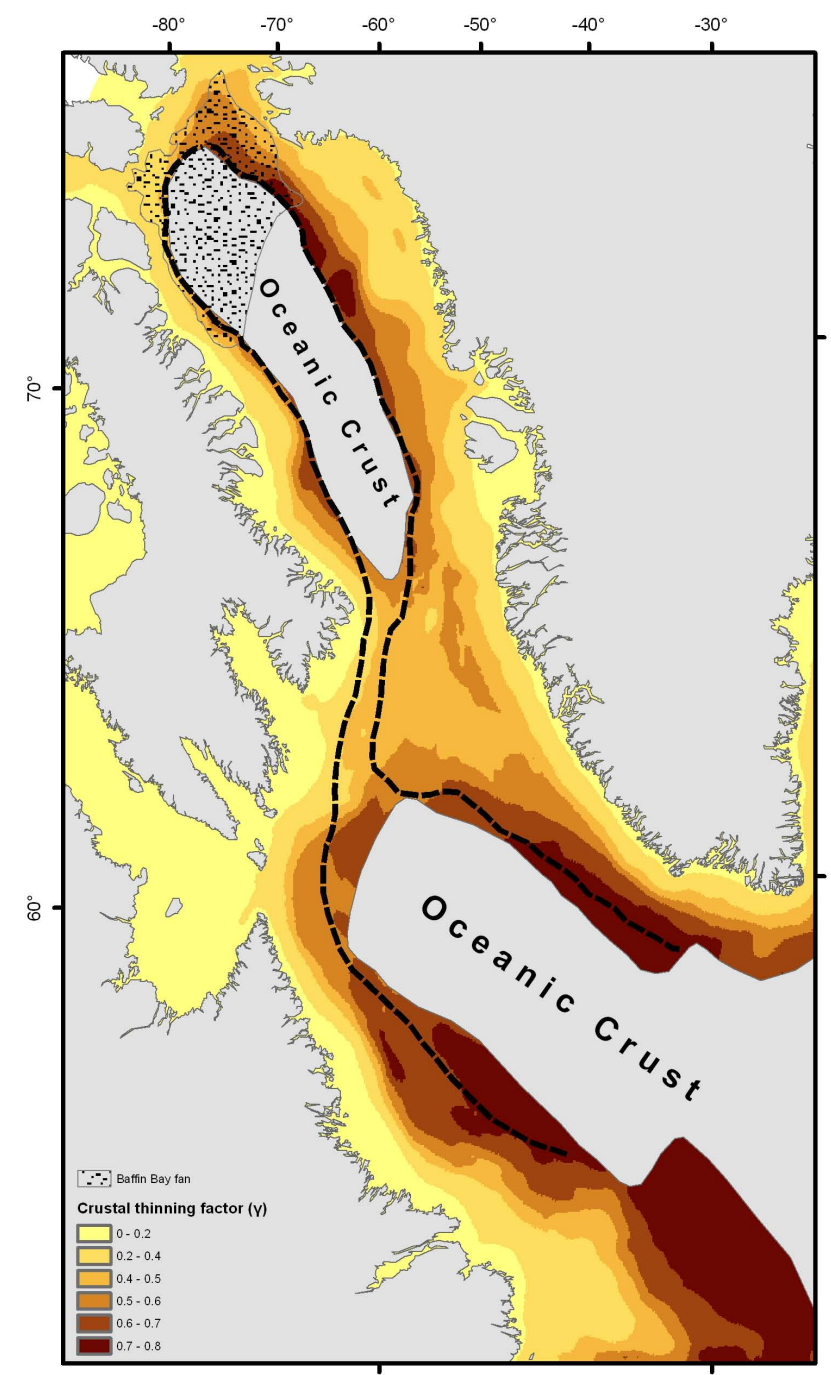

Fig. 10. Crustal thinning factor $(\gamma)$ grid varies between 0 in unstretched continental crust and more than 0.7 , which is the representative of volcanic addition in the form of magmatic underplating or oceanic crust. The thick dashed line is our preferred COB (model 7) that remains approximately at $\gamma=0.5-0.7$

crustal thickness changes from 30 to $46 \mathrm{~km}$ in North America and 33 to $48 \mathrm{~km}$ in western and central Greenland.

Welford and Hall (2013) produced a crustal thickness map for the Labrador Sea and generated maps of estimated stretching factors. They also noted large differences in the thickness of unstretched crust beneath Labrador and Greenland, between 30 and $50 \mathrm{~km}$, and compared stretching factors assuming both a uniform crustal thickness before stretching of $35 \mathrm{~km}$, and with the initial crustal thickness varying from $\sim 50 \mathrm{~km}$ beneath southern Labrador to $\sim 34 \mathrm{~km}$ beneath Baffin Island. They found that the stretching factors were not significantly altered between these two approaches, with the exception of the offshore extension of the Grenville province 
in southern Labrador, where the crustal thickness from gravity data was underestimated.

Based on this information and to resolve the effect of changing this limit for the $\mathrm{COB}$ restoration and final fit, we defined three sets of UCCLs at 35, 37 and $40 \mathrm{~km}$ crustal thickness boundaries and restored the COBs of model 7 with each of them (Figs. 7 and B3). Distribution of the crust with thickness more than $40 \mathrm{~km}$ is limited, so we set the upper limit of the UCCL range to around 40km. The location of the UCCL for all other models is fixed at $37 \mathrm{~km}$ and the only difference is in the position of COBs along both margins. We used the stage poles of rotation of Roest and Srivastava (1999) for restoration, which represent the direction of the motion of extended continental crust during the rifting between Greenland and North America. These stage poles of relative motion were used to generate small circle motion paths between two limits of extended continental crust. Crustal thicknesses from the crustal thickness grid are then extracted along these small circles to estimate the thickness of crust between two boundaries. Next, we calculate the length of this crust before extension and restore the crust to its initial reference thickness before being subjected to extension. Applying the change in crustal length along the given small circle gives the restored COB (RCOB). Repeating this process for all small circles along the margins results in a continuous model for the RCOB location.

\subsection{Reconstruction of restored COBs}

For each model described above, we use the generated RCOBs to compute poles of rotation for the pre-rift fit between Greenland and North America. The computation of Euler poles of rotation has been performed using the Hellinger (1981) least-squares fitting method. This method is typically applied to reconstructions of seafloor spreading using isochrons and fracture zones as constraints. Here, we apply the method to derive full-fit poles of rotation in the same manner as used for the Australia-Antarctic margins by Williams et al. (2011). The Euler pole of rotation calculated for the alternative models from the beginning of rifting (120 Ma) to the start of seafloor spreading (chron 27, $63 \mathrm{Ma}$ ). All reconstructions are using crustal thickness grids derived from the gravity inversion method in which igneous crust added to the thinned continental crust is removed. North America is considered as the fixed plate in all reconstructions. The main inputs for geometrical fitting of the margins are the RCOBs, which constrain the amount of closure between the two plates. To constrain the lateral juxtaposition of Greenland and North America prior to rifting, we use older structural features and terranes mapped and correlated between these two continents as follows (Fig. 12):

1. Southern border of Committee-Melville orogen (CMO) separating this area in the north from FoxeRinkian fold belt in the Baffin Island and Greenland margins (Dawes, 2009).
2. Baffin and Disko Bugt suture zones (DBS) that closed at approximately $1.88 \mathrm{Ga}$. The Baffin suture zone thrust the Meta Incognita microcontinent over the Cumberland Batholith in North America. Similarly, closure of the DBS in Greenland led to the expansion of the Aasiaat domain over the Rae craton (St-Onge et al., 2012).

3. Nordre Isortoq suture zone (NIS) $(1.86-1.84 \mathrm{Ga})$ that formed due to collision of the Aassiaat domain with the Archean North Atlantic craton along the northern boundaries of the latter.

4. Kanairiktok shear zone $(1.89-1.8 \mathrm{Ga})$ that separates Makkovik province on the Canadian side and Ketilidian orogen on the Greenland side from the Archean North Atlantic craton.

\section{Results}

We carried out restoration and reconstruction of RCOBs for the all end-member models discussed above. Restored COB locations and small circle paths for model 1 and 7 are presented in Fig. 11; the restored COBs and small circle paths for the other proposed models can be found in Appendix B, Fig. B1. Model 1 is very similar to the Srivastava and Roest (1989) model in terms of what they proposed as the location of $\mathrm{COB}$, which put the $\mathrm{COB}$ in the most landward position compared to all other models. Model 7 resulted in the best fit amongst all examined models

The most dramatic differences in the position of the RCOB occur in the Greenland margin in the northern Labrador Sea near Davis Strait. Davis Strait shows the greatest amount of extension in all models, which is mostly concentrated on the Greenland margin. The smallest amount of continental extension was observed in the model 1 , where the most landward COB follows the continental slope (Fig. 11a). The amount of continental extension in this model varies between 6 and $100 \mathrm{~km}$ in both margins. This amount of extension is the least in comparison with the other models, implying less continental thinning.

The position of the restored COBs along both margins in Baffin Bay does not change significantly for all tested models. In all models, small circles show a NW-SE direction of extension and are perpendicular or highly oblique to the coastline.

Full-fit reconstructions for our preferred model 7 and for model 1 are shown in Fig. 13. Table 1 summarises the location of Euler poles for full-fit reconstructions and their errors for all models, whereas Table 2 reviews the parameters used to calculate the rotation poles. See Appendix B, Fig. B2 for reconstructions for the other models presented here.

Model 1 shows a reasonable fit in the southern Labrador Sea and Baffin Bay, but further north there is a major gap in the northern Labrador Sea near Davis Strait and an overlap 


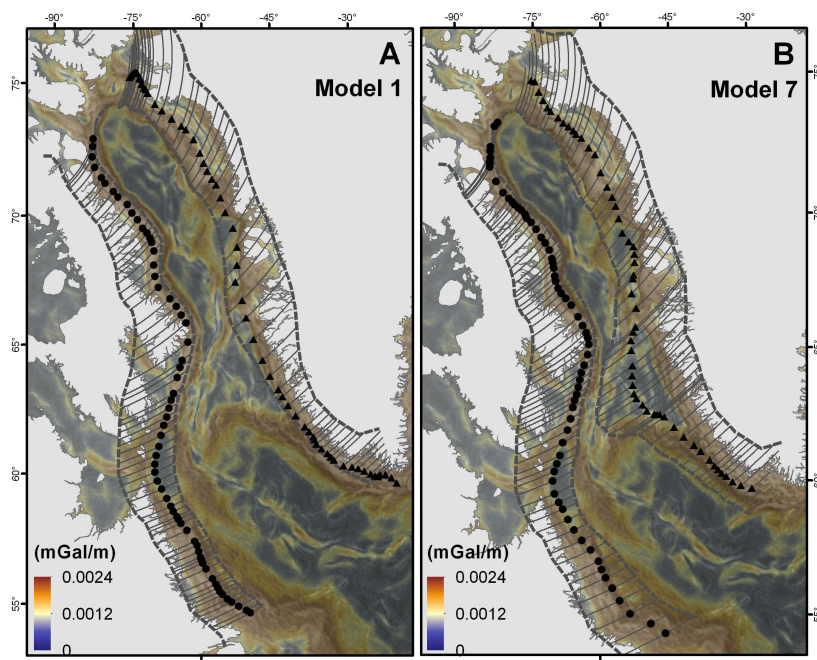

Fig. 11. Restored COBs on North America and Greenland margins together with small circle paths showing the direction of restoration. The dashed lines are the UCCL and COB lines before the restoration was performed. The background is total horizontal gradient of Bouguer gravity map. Model 1: Srivastava and Roest (1989) COBs. Model 7: our preferred model assuming the COB in the range of COT, and UFZ as leaky transform fault in Davis Strait. Restored COB locations: triangles - Greenland margin; circles North American margin.

north of Disko Island (Fig. 13). This model is very similar to the Srivastava and Roest (1989) reconstruction for the onset of rifting except that model 1 locates Greenland slightly further south relative to North America.

The most dramatic improvement in the fit reconstruction of model 7 is achieved in the northern Labrador Sea and Davis Strait, which are the two most problematic and controversial regions. This model reinforces the hypothesis of the existence of a narrow Palaeocene oceanic basin in that region. Figure B2-H (model 8) demonstrates the full-fit reconstruction using the UCCL-COB borders of model 7, while it uses the crustal thickness grid excluded from the igneous post-rift material. Model 8 appears to slightly increase the adjustment of restored COBs, especially in the Labrador Sea and Davis Strait when compared to model 7; however, due to lots of uncertainties in placement and the amount of underplated material, especially where we lack seismic data, this model should be treated more carefully. Our proposed models correlate juxtaposed Precambrian rocks in North America and Greenland margins well.

\section{Discussion}

\subsection{Non-rigid Greenland-North America}

Previous attempts to reconstruct Cretaceous rifting between Greenland and North America have produced major gaps

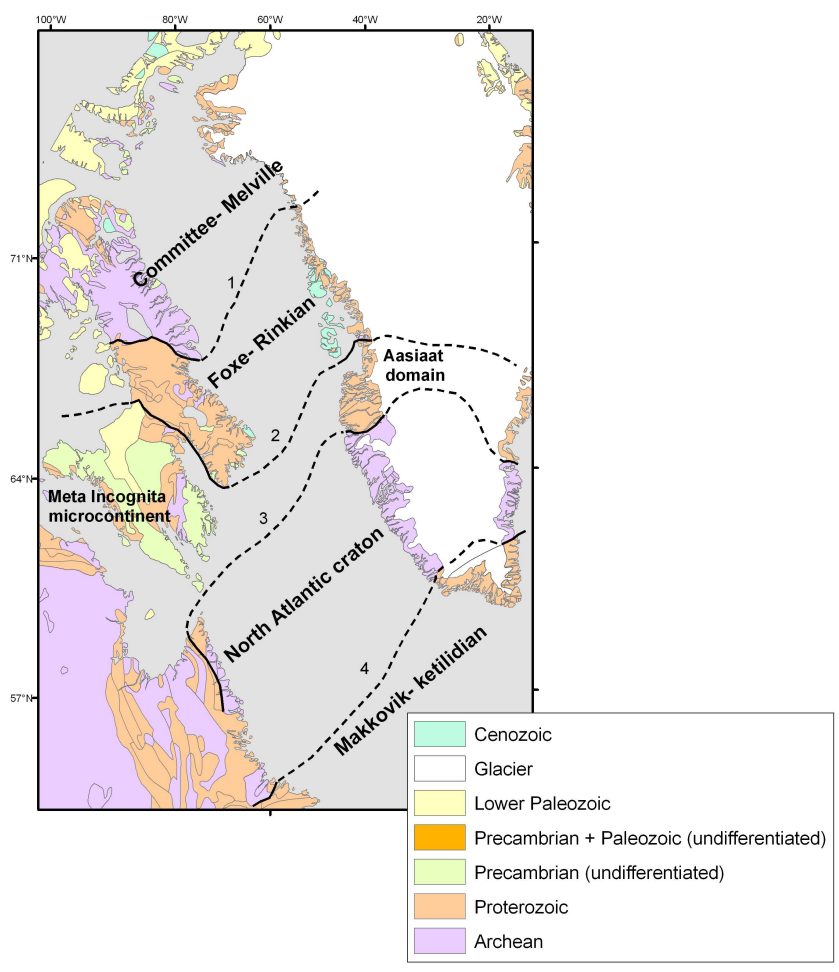

Fig. 12. Geological map of North America and Greenland (Bouysse, 2010) used for lateral correlation of two margins. We use sedimentary formations and rock units older than Palaeozoic to correlate the full-fit alignment of the conjugate margins. Numbers refer to structural features separating those units and formations that have been mentioned and discussed in more detail in the main text.

and/or overlaps, leading to some suggestions that the two plates need to be treated as non-rigid continents. Small amounts of late Cretaceous-early Palaeogene extension in Canada (Okulitch et al., 1990) was proposed for North America as a deforming plate for alleviating overlaps in Davis Strait (e.g. Srivastava and Falconer, 1982 and Lawver, 1990). The evidence for this extension comes from mapping features in Hudson Strait and Foxe Channel (Jackson and Ianelli, 1981). A recent study by Pinet et al. (2013) in Hudson Strait and Foxe Channel reported normal fault-dominated sub-basins with thicker sedimentary succession that are interpreted as syn-rift strata. This study investigated the relationship between formation of these basins and the early rifting of the Labrador Sea, but this connection is not clear, mainly because of lack of information about the age of upper limit of sediment and the amount of extension happened in this area.

An alternative mechanism to improve the pre-rift fit has been to invoke deformation within Greenland. Studies in western Greenland support the existence of several shear zones within the boundaries of the Nagssugtoqidian orogenic belt (the area between structural features 3 and 4 in Fig. 13) (Bak et al., 1975; Wilson et al., 2006). Beh (1975) and Srivastava and Faconer (1982) invoked a number of sinistral 
Table 1. Full-fit rotation parameters for alternative models of Greenland relative to North America (fixed) discussed in this paper. The chron 27 pole of rotation derived from Oakey and Chalmers (2012) has also been represented.

\begin{tabular}{llllllllll}
\hline \multicolumn{9}{c}{ Full fit (120 Ma) } \\
\hline Model & $\begin{array}{l}\text { Latitude } \\
(\mathrm{deg})\end{array}$ & $\begin{array}{l}\text { Longitude } \\
(\mathrm{deg})\end{array}$ & $\begin{array}{l}\text { Angle } \\
(\mathrm{deg})\end{array}$ & $\begin{array}{l}r \\
(\mathrm{~km})\end{array}$ & $\hat{\kappa}$ & $\mathrm{dF}$ & $N$ & $s$ \\
\hline 1 & 63.92 & -124.47 & -13.51 & 946.01 & 0.12 & 116 & 127 & 4 \\
2 & 61.00 & -129.40 & -11.16 & 644.74 & 0.16 & 106 & 117 & 4 \\
3 & 62.82 & -129.87 & -11.28 & 634.35 & 0.17 & 109 & 120 & 4 \\
4 & 59.98 & -134.69 & -9.67 & 818.34 & 0.15 & 123 & 134 & 4 \\
5 & 60.88 & -132.94 & -10.00 & 672.62 & 0.17 & 116 & 127 & 4 \\
6 & 59.73 & -132.55 & -10.23 & 769.08 & 0.13 & 106 & 117 & 4 \\
7 & 61.67 & -131.80 & -10.47 & 678.16 & 0.15 & 107 & 118 & 4 \\
8 & 64.18 & -131.88 & -10.67 & 435.79 & 0.23 & 104 & 115 & 4 \\
\hline Chron 27 & 27.8 & -150.0 & -3.75 & & & & & \\
\hline
\end{tabular}

Parameters are $r$, total misfit; $\hat{\kappa}$, estimated quality factor; $\mathrm{dF}$, degree of freedom; $N$, number of data points; and $s$, number of great circle segments. Model 8 uses the same COBs as model 7 except that the restoration has been performed using the crustal thickness grid with igneous material subtracting from it.

Table 2. Rotation covariance for North America-Greenland reconstructions.

\begin{tabular}{lrrrrrr}
\hline Model & $a$ & $b$ & $c$ & $d$ & $e$ & $f$ \\
\hline 1 & 9.08 & 7.57 & 1.79 & 3.10 & -9.56 & 7.31 \\
2 & 1.11 & 3.29 & 2.75 & 2.77 & -3.23 & 1.18 \\
3 & 1.00 & 7.80 & 2.45 & 2.19 & -2.27 & 9.94 \\
4 & 1.12 & -9.90 & 2.99 & 1.85 & -2.56 & 1.20 \\
5 & 8.80 & 5.66 & 2.17 & 2.06 & -2.38 & 9.56 \\
6 & 9.62 & 4.57 & 2.45 & 2.24 & -2.62 & 1.09 \\
7 & 9.63 & 9.13 & 2.39 & 2.13 & -2.39 & 1.03 \\
8 & 7.81 & -1.20 & 2.12 & 1.96 & -2.81 & 1.00 \\
\hline
\end{tabular}

The covariance matrix is given by the formula $\frac{1}{\kappa} \times b d e \times 10^{-g}$, where

the values " $a$ " to " $f$ " are given in radians squared.

$c e f$

shear zones crossing central Greenland on the basis of what Beh et al. (1975) suggested considering geological information and the physiography of the glacial channels running through Greenland. A similar shear zone has been contemplated in a recent Arctic reconstruction (Winefield et al., 2011). These structures have been mapped only in the Archaean and Proterozoic rocks near the margin and the continuation of these tectonic features inland and under the ice cover of the Greenland, and any reactivation and displacement along these faults during late Cretaceous rifting is as yet undocumented.

Our analysis suggests that full-fit reconstructions treating Greenland and North America as rigid blocks with deforming margins achieve a relatively good overall fit, including in areas such as Davis Strait, where the distribution of crustal types remains unclear. Our preferred model 7, as well as the range of models presented here testing the sensitivity of our results to different starting assumptions, shows that internal

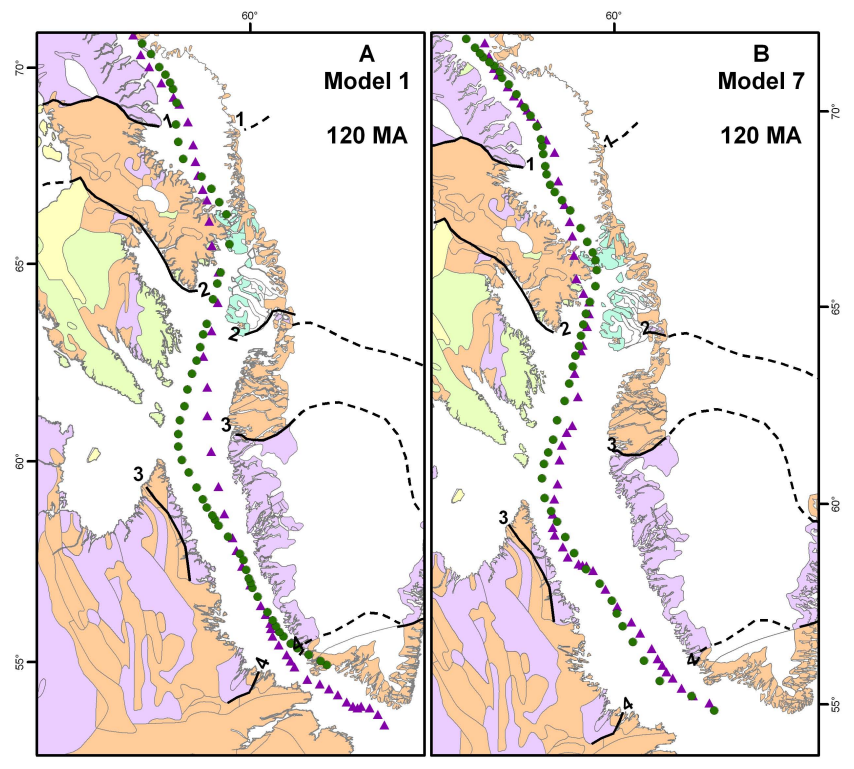

Fig. 13. Full-fit (120 Ma) plate reconstruction of North AmericaGreenland margins. North America restored COB - green circles; Greenland restored COB - purple triangles. (A) Model 1 results in a major overlap in the northern Labrador Sea near Davis Strait. (B) Model 7 minimises the mismatch in this area and results in a good fit in both the Labrador Sea and Baffin Bay. Structural lines are the same as Fig. 11 and are represented here to show the lateral juxtaposing of the margins.

deformation within Greenland and/or North America is not necessary to restore these plates to their configuration at the onset of rifting and opening of the Labrador Sea and Baffin Bay. 


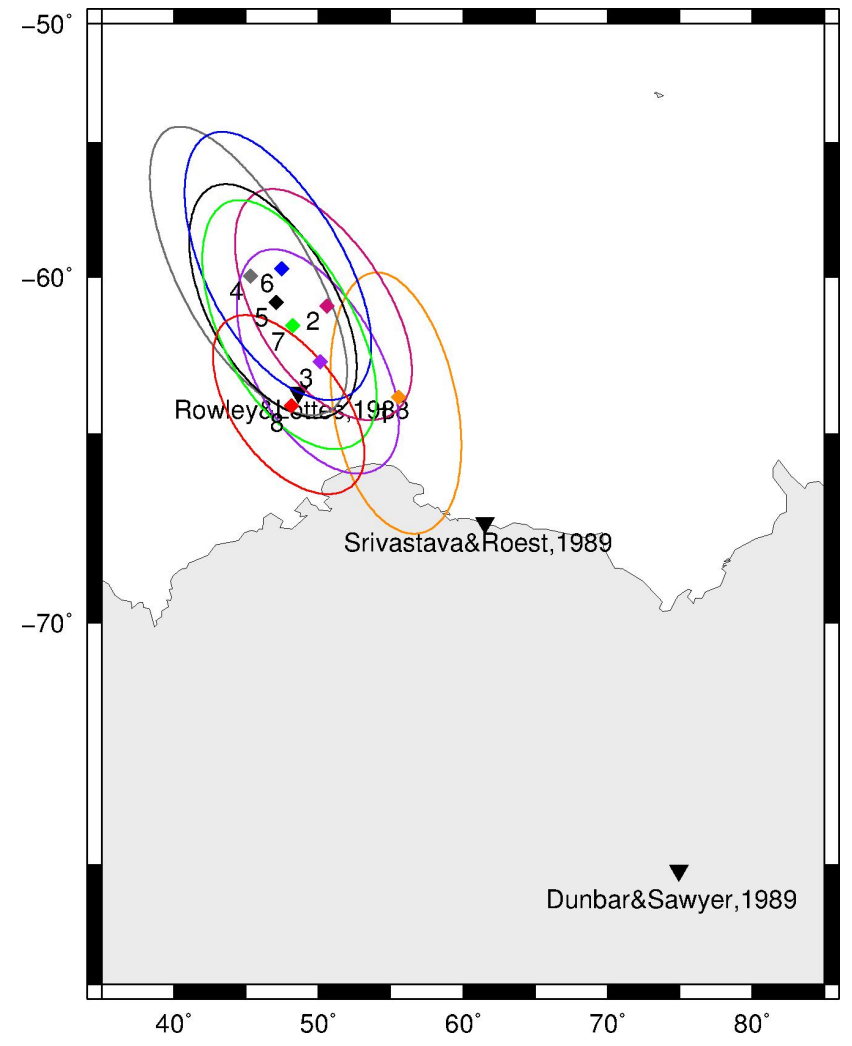

Fig. 14. Comparison of previously published and our computed Euler poles with $95 \%$ uncertainty ellipses. The numbers represent the models described in the text.

\subsection{Comparing previous models and our preferred model}

Figure 14 shows the comparison between the location of the Euler poles and their uncertainty ellipses of our alternative models together with the full-fit Euler poles from previous studies. The Euler poles resulting from different models proposed here vary within a very limited geographical range and their error ellipses mostly overlap. The pole resulting from model 1 is the closest to the rotation pole proposed by Srivastava and Roest (1989). This similarity can be explained by the almost identical interpretations of these models concerning the nature of the crust adjacent to both margins. Of the previously published models, the full-fit rotation pole of Rowley and Lottes (1988) is located closest to model 8. The smaller error ellipse of model number 8 compared with all other models is noticeable.

\subsection{Continental rift phase}

Our reconstruction based on restoring extended continental crust gives us a full-fit reconstruction pole at the onset of continental rifting $(\sim 120 \mathrm{Ma})$. Since the oldest reliable seafloor spreading isochron within the Labrador Sea is chron 27, the next more recent time for which we have a quantitatively constrained reconstruction is $\sim 63 \mathrm{Ma}$ (Oakey and Chalmers, 2012). We now use our preferred reconstruction and COT configuration to investigate the diachronous transition from continental rifting to the onset of formation of the transition zone and seafloor spreading, assuming a constant rate and direction of rotation of Greenland away from North America and considering possible deviations from this simple assumption.

Reconstruction from 120 to $85 \mathrm{Ma}$ shows that extending continental crust during this time spans the entire region in between North America and Greenland. At $85 \mathrm{Ma}$, Baffin Bay is still underlain entirely by continental crust, but further south crust now contained within the COT of the Labrador margins has begun to form (Fig. 15a). By $69 \mathrm{Ma}$, large regions of the Labrador Sea are underlain by COT crust although, based on our preferred COBs from assimilation of seismic data, continental connection persists at the junction between the Labrador Sea and Davis Strait (Fig. 15b). Oblique opening of Davis Strait around this time suggests that the oldest igneous crust within the UFZ, proposed as a leaky transform fault (Funck et al., 2007, 2012), could be late Cretaceous in age. Unequivocal chron 27 seafloor spreading anomalies are observed in the Labrador Sea (Fig. 15c). The existence of oceanic crust in Baffin Bay, possibly younger than chron 27 (late Palaeocene, chron 26), has also been proposed (e.g. Suckro et al., 2012; Oakey and Chalmers, 2012) that is consistent with our model. The reconstruction of Oakey and Chalmers (2012) predicts that the earliest ocean crust in Baffin Bay formed during broadly NE-SW spreading, followed by a change to more oblique $\mathrm{N}-\mathrm{S}$ extension between chrons 25 and 24 (57-54 Ma) (Fig. 15d). Reconstructions constrained by seafloor spreading anomalies and fracture zones suggest that this direction of relative motion persisted until the cessation of spreading between North America and Greenland around chron 13 time (Roest and Srivastava, 1989; Oakey and Chalmers, 2012; Suckro et al., 2012). Seafloor spreading within Baffin Bay and the Labrador Sea occurred contemporaneously with strike-slip and transpressional deformation within Davis Strait (Suckro et al., 2013).

The discussion above assumes a uniform rate and direction of relative motion during continental rifting and the formation of the transition zone. Other geological evidence is necessary to make such inferences. For example, Døssing (2011) presented a detailed study of the Fylla Structural Complex (Fig. 1) located on the western Greenland margin in the north Labrador Sea near Davis Strait. The complex is composed of rift basins that initiated in the late-early Cretaceous. Following a phase of major uplift, characterised by an erosional unconformity, further episodes of rifting occurred in the Campanian and early Cenozoic. The inferred stress regime changes significantly between these different rift phases, with dominantly NE-SW extension in the lateearly Cretaceous followed a clockwise rotation on the extensional stress direction to E-W to ENE-WSW by the early Campanian. 


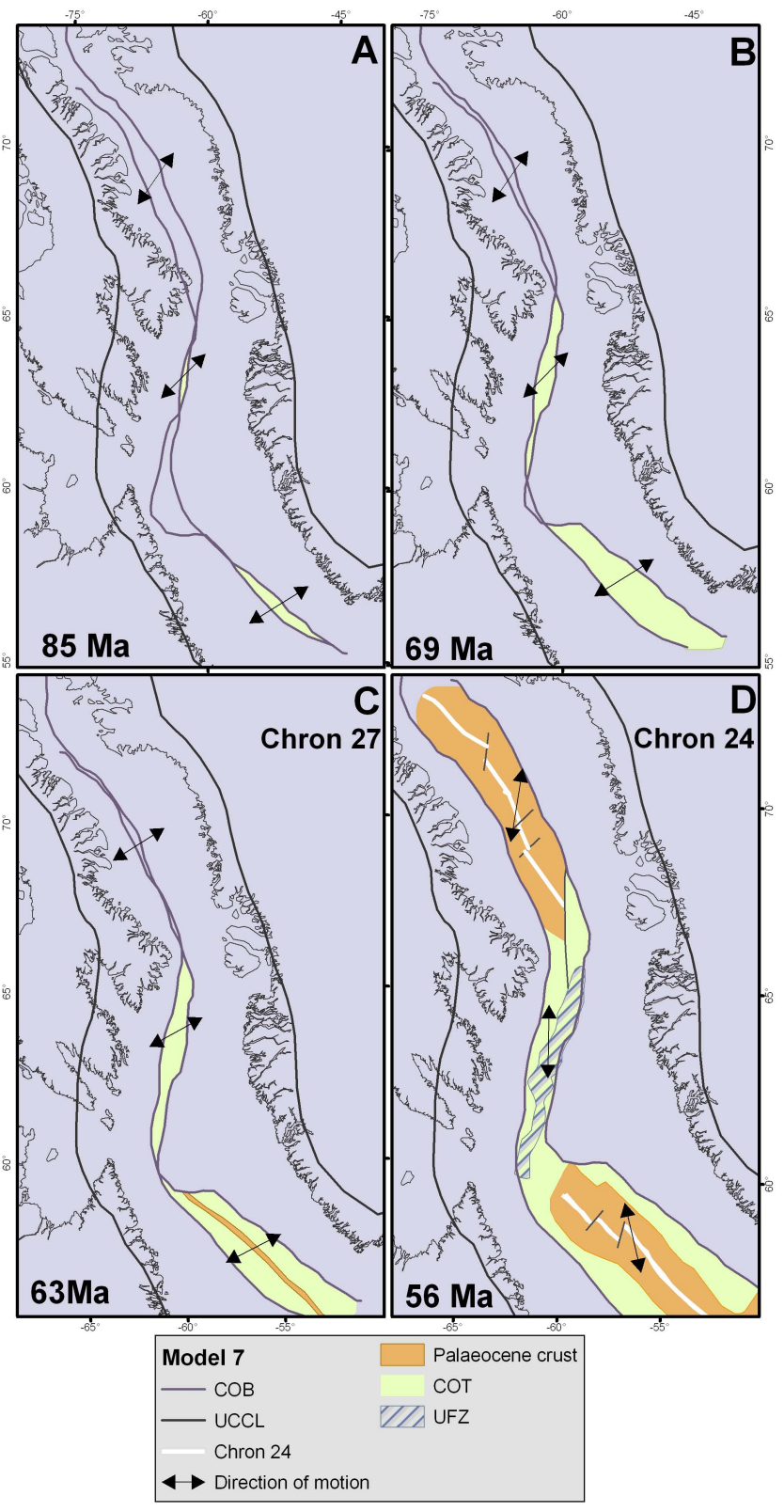

Fig. 15. Reconstruction of the rifting and seafloor spreading in the Labrador Sea and Baffin Bay. The models use the rotation pole from model 7 UCCL and COBs (purple lines) for the rifting period (120 up to $63 \mathrm{Ma}$ ). Seafloor spreading (63 Ma and younger) has been reconstructed using Oakey and Chalmers (2012) poles of rotation.

Tectonostratigraphic studies of the North American margin of the Labrador Sea also show an early rifting phase during the early Cretaceous, characterised by widespread extensional faulting and formation of grabens and half-grabens (Dickie et al., 2011). Regional unconformities in the midCretaceous (100-83 Ma) are considered too early to be related to continental breakup, and may instead be related to changes in the magnitude and/or direction of the stress field (Dickie et al., 2012, and references therein).
Subsidence curves calculated from wells in the Hopedale Basin (Fig. 1) consistently show the onset of rapid subsidence around $70 \mathrm{Ma}$, interpreted to coincide with the onset of seafloor spreading in the Labrador Sea (Dickie et al., 2012).

A limitation of using crustal thickness restoration is that these data do not allow us to quantitatively constrain changes in plate motion during the rifting. Our reconstruction describes the overall motion between Greenland and North America from the beginning of rifting $(\sim 120 \mathrm{Ma})$ until the time of the earliest seafloor spreading anomaly (63 Ma), which varies from ENE-WSW in the southern Labrador Sea to NE-SW in Baffin Bay. The studies discussed above are consistent with the overall motion implied by our reconstruction while providing evidence for distinct stages within this overall motion. However, the available data are insufficient to constrain this in a quantitative manner. As shown for the Australian and Antarctic margin, reconstructions derived using the method applied here are relatively insensitive to changes in the direction of relative plate motions (Williams et al., 2011). Hence our reconstruction forms a starting point for more detailed models of Cretaceous continental rifting between Greenland and North America.

\section{Conclusions}

We derive a new full-fit reconstruction that restores the Greenland and North American plates to their configuration prior to Cretaceous rifting. In contrast to previous early Cretaceous reconstructions, our study incorporates new interpretations of thinned and stretched crust in the margins of the Labrador Sea, Baffin Bay and Davis Strait as either a continental or transitional crust consisting of a mixture of serpentinised mantle with slivers of continental crust and igneous material. We quantify the extension and thinning of continental crust and restore the COBs to their pre-rift configuration and test the sensitivity of these results to different interpretations of the crustal types within the COT. The model that best fits the entire region (model 7) was generated with a $\mathrm{COB}$ within the bounds of all available seismic interpretations and oceanward of magnetic anomalies previously interpreted as chron 31 in the Labrador Sea. Within the best-fitting model, the UFZ is considered as a leaky transform fault that produces a narrow strip of igneous crust through Davis Strait.

Our results imply that an acceptable fit between Greenland and North America can be achieved without the need for large-scale deformation within either these plates. Assuming a constant rate and direction of rifting from the beginning of rifting to the start of seafloor spreading, our best defined model 7 shows the generation of post-rift material within the present-day COT started in the southern Labrador Sea and propagated northward. 


\section{Appendix A}

\section{Mapping crustal thickness by gravity inversion}

We derived a map of Moho depth for the Labrador Sea, Davis Strait and Baffin Bay by inversion of gravity data; our method follows an approach similar to that used by Greenhalgh and Kusznir (2007) and Chappell and Kusznir (2008) to map crustal thickness at continental margins of the northeast Atlantic. We estimate and strip away the gravity effects of sea water, sediment layers and density variations within the mantle based on variation in the age of oceanic lithosphere.

We use gravity data derived from satellite altimetry over the oceans (Sandwell and Smith, 2009), which incorporates the EGM08 gravity model for onshore areas. We calculated an onshore simple Bouguer correction using the EGM08 elevation model and a Bouguer correction density of $2.67 \mathrm{~g} \mathrm{cc}^{-1}$. For Greenland, the corrections also take into account the thickness of ice taken from (Bamber et al., 2001) and use a density for ice of $0.91 \mathrm{~g} \mathrm{cc}^{-1}$.

To estimate the gravity effect of the sediment layers, we use sediment thickness grids from Louden et al. (2004) for the Labrador Sea and Davis Strait. We merged this map with less detailed data for Baffin Bay taken from the compilations of Divins (2003) and Bassin et al. (2000). A 3-D distribution of sediment density was derived using a depth-density function based on the equations and empirically derived constants given by Sawyer (1985).

A lithosphere thermal gravity anomaly correction was calculated by first deriving a 3-D model of the lithosphere temperature beneath the basin. Beneath the oceanic lithosphere the thermal structure is estimated using a 1-D cooling model (McKenzie, 1978), which provides an adequate approximation to 2-D thermal models (Chappell and Kusznir, 2008). For the distribution of seafloor age we use a modified version of the age grid presented by Müller et al. (2008). The grid of Müller et al. (2008) contains ocean crust in Davis Strait and along the Labrador Sea margins based on the interpretation of seafloor up to chron 33 age from Roest and Srivastava (1989). As discussed in the main text, a synthesis of currently available seismic profile interpretations suggests much of this area is underlain by either stretched continental crust or the COT; see Figs. 2 to 5. We therefore mask the Müller et al. (2008) age grid to for these areas. Following Breivik et al. (1999) and Kimbell et al. (2004), we model the temperature in the region of stretched continental crust is modelled using a ramp between the oceanic domain and a separate model for the lithosphere temperature under stable continental areas. In this way a 3-D grid of lithospheric temperature field is calculated at a resolution of $5 \mathrm{~km}$. From this, we derive a 3-D density field and gravity field observed at the surface as described by Chappell and Kusznir (2008).
After application of all the gravity corrections described above, the remaining gravity signal is inverted using the method of Parker (1972) to derive a map of depth to the Moho. The results are influenced by a range of assumptions involved, notably the density contrast across the Moho, and the reference Moho depth. (The thickness of crust corresponds to zero bathymetry and zero long-wavelength freeair gravity; Alvey et al., 2008). We tested a range of parameter combinations (Fig. A1) and validated the results by plotting the gravity inversion depths against independent estimates of the Moho depth from seismic refraction profiles and receiver functions studies at onshore seismic stations. The lowest RMS difference between the gravity and seismic refraction corresponds to a reference depth of $37 \mathrm{~km}$ and density contrast across the Moho of $500 \mathrm{~kg} \mathrm{~m}^{-3}$ (the RMS for values of $38 \mathrm{~km}$ and $450 \mathrm{~kg} \mathrm{~m}^{-3}$ are very similar). The reference depth is important for our purpose, since we use this value as the thickness of continental crust prior to extension in the cross-section area balancing. We find the value used for the reference Moho depths (Zref) has two counteracting effects on the location of the restored COB locations. A larger Zref value yields a greater volume of continental crust within the margin, so it tends to move the RCOB location more oceanward; however, the larger Zref is also used in the area-balancing and it moves the RCOB landward.

Seismic data (e.g. Funck et al., 2007; Skaarup et al., 2006; Gerlings et al., 2009) show that Davis Strait is heavily affected by magmatic addition related to the passage of the Iceland plume underneath the area during the early Palaeocene. Chappell and Kusznir (2008) describe an approach to estimate the amount of magmatic addition based on stretching factors obtained from the gravity inversion crustal thickness. However, compression in this area, illustrated by observations and plate motions (Oakey and Chalmers, 2012), makes it complicated to estimate stretching factors for the earlier extension (and therefore volumes of magmatic addition) directly from present-day crustal thickness estimates. We can draw insights from direct comparison between our estimated Moho depths and the distribution of what previous authors interpret as underplating along seismic refraction profiles. For profiles across Davis Strait, our preferred Moho depth typically lies shallower than the refraction Moho where underplating is interpreted beneath continental crust on NUGGET lines 1 and 2 (Funck et al., 2007; Gerlings et al., 2009). The preferred gravity Moho lies slightly above the base of the crust in the refraction profile presented by Suckro et al. (2013), although the gravity Moho falls significantly below the refraction interpretation at the western margin of the line. The implications of interpreted underplating within Davis Strait for our reconstructions are discussed further in the main text. 

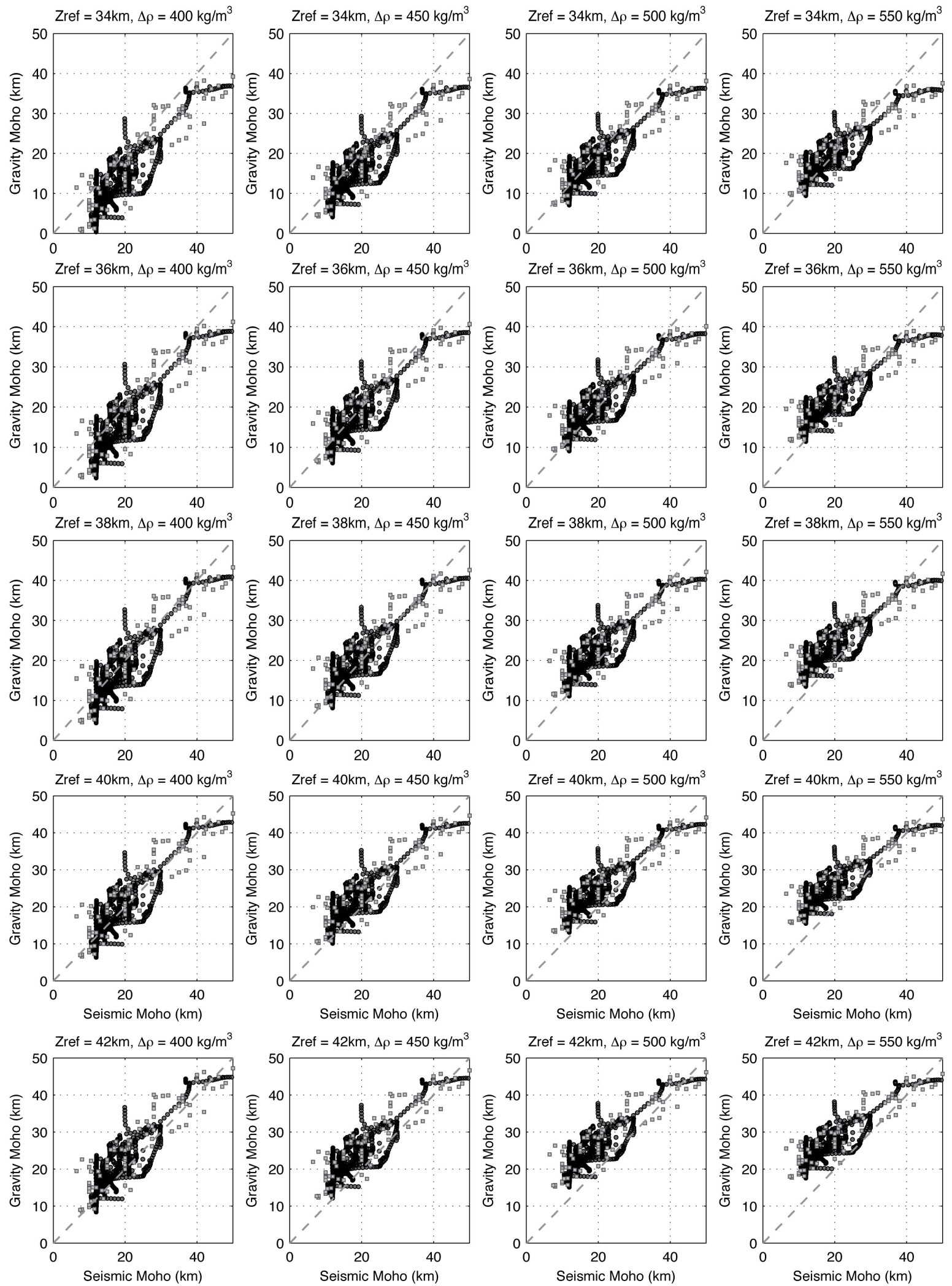

Fig. A1. Verification of the credibility of gravity inversion method and the resulting crustal thickness grid. The results were tested by different combinations of reference Moho depths (Zref) and crustal densities $(\Delta \rho)$ ). The gravity Moho in each combination (circles) has been plotted against the depth to Moho derived from independent seismic refraction profiles and receiver functions (squares) to examine their correspondence and validity. 

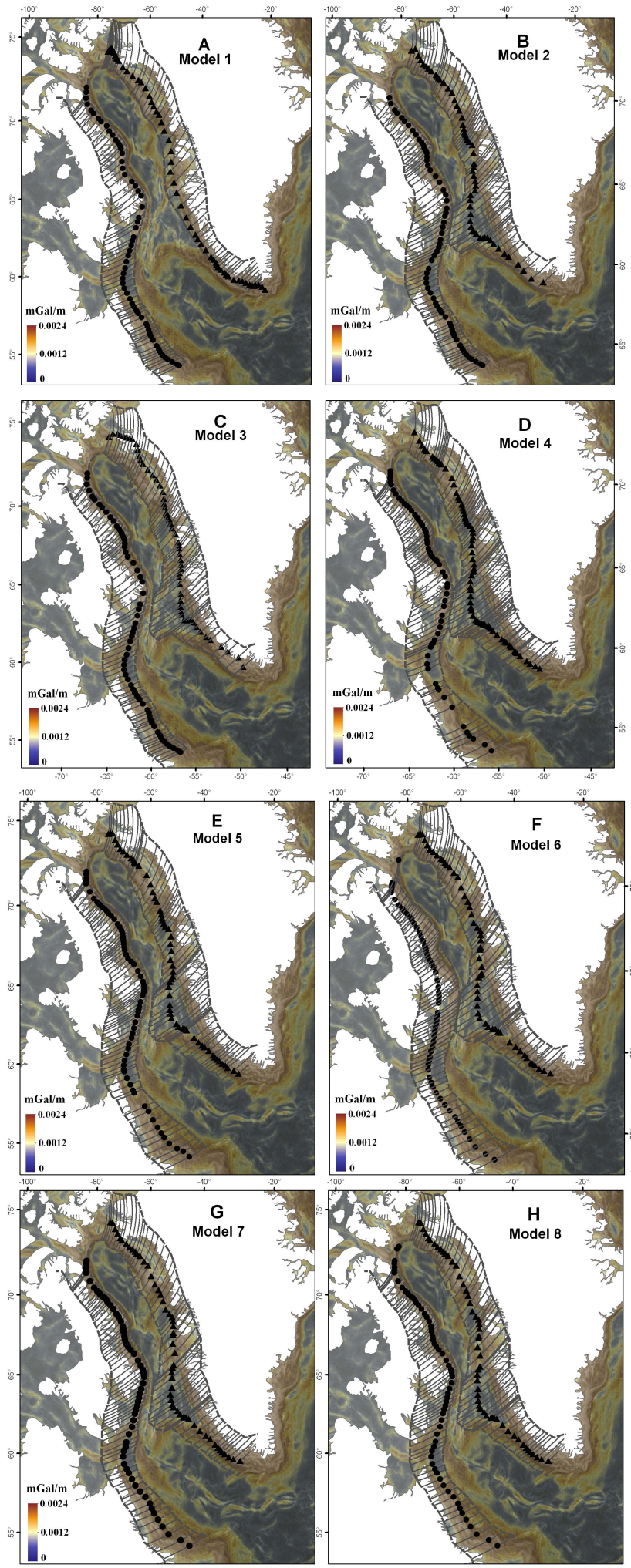

Fig. B1. Restoration of present-day COBs in to their pre-rift positions in conjugate margins. The restoration has been applied for the all eight models in this study. UCCL lines and present-day COBs have been shown in grey dashed lines, while the restored COBs are shown as black circles for the North America and black triangles for the Greenland margin. Thin solid lines are small circle paths showing the direction of motion during the restoration process. The background map is the total horizontal gradient of Bouguer gravity map corrected from EGM08 gravity model.
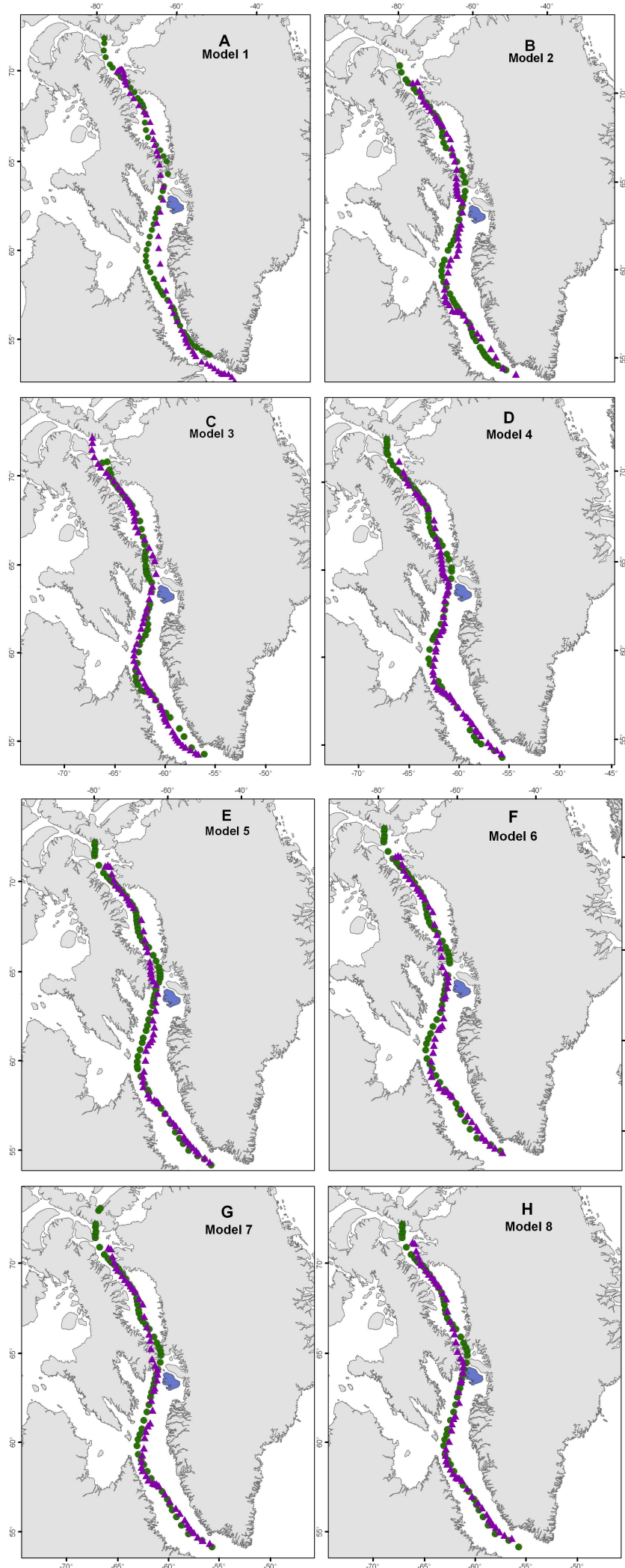

Fig. B2. Alternative full-fit (120 Ma) plate reconstruction of North AmericaGreenland margins for all of the models tested in this study. North America restored COB has been shown in green circles while Greenland COB is shown in purple triangles. Disko Island is highlighted in blue in all models to make the comparison easier. 


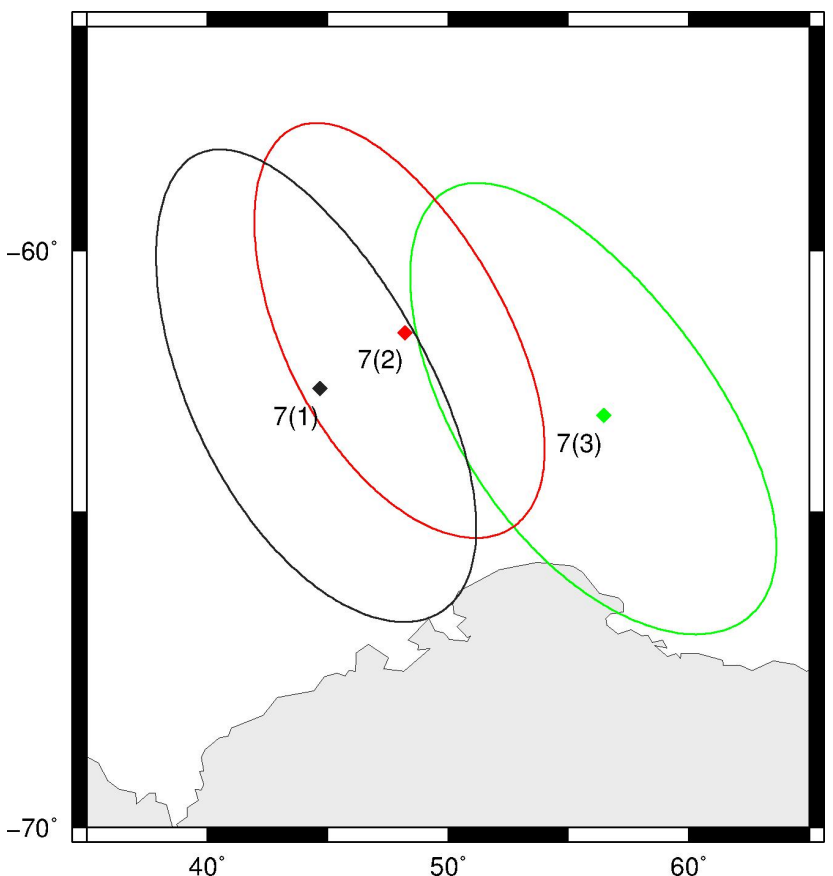

Fig. B3. $95 \%$ uncertainty ellipses for model 7 running with three different sets of UCCL. 7(1) corresponds to the crustal thickness $\sim 40 \mathrm{~km}$. Numbers 2 and 3 are are the limit of 37 and $34 \mathrm{~km}$ respectively.

\section{Supplementary material related to this article is available online at http://www.solid-earth.net/4/461/ 2013/se-4-461-2013-supplement.zip.}

Acknowledgements. M. Hosseinpour, S. E. Williams and R. D. Müller gratefully acknowledge the support received from the ARC through grant no. FL0992245. M. Hosseinpour also expresses gratitude for the CSIRO OCE Ph.D. scholarship. J. M. Whittaker wishes to thank Statoil for the support provided. We also thank F. Rossetti for their constructive reviews.

Edited by: F. Rossetti

\section{References}

Alvey, A., Gaina, C., Kusznir, N., and Torsvik, T.: Integrated crustal thickness mapping and plate reconstructions for the high Arctic, Earth Planet. Sci. Lett., 274, 310-321, 2001.

Bak, J., Korstgård, J., and Sørensen, K.: A major shear zone within the Nagssugtoqidian of West Greenland, Tectonophysics, 27, 191-209, 1975

Bamber, J. L., Layberry, R. L., and Gogineni, S. P.: A new ice thickness and bed data set for the Greenland ice sheet 1. Measurement, data reduction, and errors, J. Geophys. Res.-Atmos., 106, 33773 33780, 2001.
Bassin, C., Laske, G., and Masters, G.: The current limits of resolution of surface wave tomography in North America, EOS Trans AGU, F897, 2000.

Beh, R. L.: Evolution and geology of western Baffin Bay and Davis Strait, Canada, 1975.

Braun, A., Kim, H. R., Csatho, B., and von Frese, R. R.: Gravityinferred crustal thickness of greenland, Earth Planet Sc. Lett., 262, 138-158, 2007.

Breivik, A. J., Verhoef, J., and Faleide, J. I.: Effect of thermal contrasts on gravity modeling at passive margins: Results from the western Barents Sea, J. Geophys. Res.-Sol. Ea., 104, 1529315311, 1999.

Bullard, E., Everett, J. E., Smith, A. G., and Everett, J.: The fit of the continents around the atlantic, Philos. Trans. R. Soc. Lond. A, 258, 41-51, 1965.

Chalmers, J. and Pulvertaft, T.: Development of the continental margins of the labrador sea: A review, Geol. Soc. London Spec. Publ., 187, 77-105, 2001.

Chalmers, J. A.: New evidence on the structure of the labrador sea/greenland continental margin, J. Geol. Soc., 148, 899-908, 1991.

Chalmers, J. A. and Laursen, K. H.: Labrador sea: The extent of continental and oceanic crust and the timing of the onset of seafloor spreading, Mar. Petrol. Geol., 12, 205-217, 1995.

Chappell, A. and Kusznir, N.: Three-dimensional gravity inversion for moho depth at rifted continental margins incorporating a lithosphere thermal gravity anomaly correction, Geophys. J. Int., 174, 1-13, 2008.

Chian, D. and Louden, K. E.: The continent-ocean crustal transition across the southwest greenland margin, J. Geophys. Res., 99, 9117-9135, 1994

Chian, D. P., Louden, K. E., and Reid, I.: Crustal structure of the labrador sea conjugate margin and implications for the formation of nonvolcanic continental margins, J. Geophys. Res.-Sol. Ea. 100, 24239-24253, 1995a.

Chian, D., Keen, C., Reid, I. and Louden, K. E.: Evolution of nonvolcanic rifted margins: New results from the conjugate margins of the labrador sea, Geology, 23, 589-592, 1995b.

Crosby, A., White, N., Edwards, G., Thompson, M., Corfield, R. and Mackay, L.: Evolution of deep-water rifted margins: Testing depth-dependent extensional models, Tectonics, 30, TC1004, doi:10.1029/2010TC002687, 2011.

Dawes, P. R.: Precambrian-Palaeozoic geology of Smith Sound, Canada and Greenland: key constraint to palaeogeographic reconstructions of northern Laurentia and the North Atlantic region, Terra Nova., 21, 1-13, doi:10.1111/j.13653121.2008.00845.x, 2009.

Dickie, K., Keen, C. E., Williams, G. L., and Dehler, S. A. Tectonostratigraphic evolution of the labrador margin, atlantic canada, Mar. Petrol. Geol., 28, 1663-1675, 2011.

Divins, D.: Total sediment thickness of the world's oceans and marginal seas, 2003.

Divins, D. L.: Total sediment thickness of the world's oceans and marginal seas, 2004.

Døssing, A.: Fylla bank: Structure and evolution of a normal-toshear rifted margin in the northern labrador sea, Geophys. J. Int., 187, 655-676, 2011. 
Dunbar, J. A. and Sawyer, D. S.: Patterns of continental extension along the conjugate margins of the central and north atlantic oceans and labrador sea, Tectonics, 8, 1059-1077, 1989.

Funck, T., Jackson, H., Louden, K., and Klingelhöfer, F.: Seismic study of the transform-rifted margin in davis strait between baffin island (Canada) and greenland: What happens when a plume meets a transform-art, J. Geophys. Res.-Sol. Ea. 112, B04402, doi:10.1029/2006JB004308, 2007.

Funck, T., Gohl, K., Damm, V., and Heyde, I.: Tectonic evolution of southern baffin bay and davis strait: Results from a seismic refraction transect between canada and greenland, J. Geophys. Res., 117, B04107, doi:10.1029/2011JB009110, 2012.

Gerlings, J., Funck, T., Jackson, H. R., Louden, K. E., and Klingelhöfer, F.: Seismic evidence for plume-derived volcanism during formation of the continental margin in southern davis strait and northern labrador sea, Geophys. J. Int., 176, 980-994, 2009.

Gradstein, F. M., Ogg, J. G., and Schmitz, M. (Eds.): The Geologic Time Scale 2012, 2-volume set, Elsevier, 2012.

Greenhalgh, E. E. and Kusznir, N. J.: Evidence for thin oceanic crust on the extinct aegir ridge, norwegian basin, ne atlantic derived from satellite gravity inversion, Geophys. Res. Lett. 34, L06305, doi:10.1029/2007gl029440, 2007.

Harrison, J., Brent, T., and Oakey, G.: Baffin fan and its inverted rift system of arctic eastern canada: Stratigraphy, tectonics and petroleum resource potential, Geol. Soc. London Memoirs, 35, 595-626, 2011.

Hellinger, S. J.: The uncertainties of finite rotations in plate tectonics, J. Geophys. Res., 86, 9312-9318, 1981.

Jackson, G. and Iannelli, T.: Rift-related cyclic sedimentation in the neohelikian borden basin, northern baffin island, Pap. Geol. Surv. Can., 81-10, 1981.

Keen, C. and Barrett, D.: Seismic refraction studies in baffin bay: An example of a developing ocean basin*, Geophys. J. Roy. Astr. S., 30, 253-271, 1972.

Keen, C. E., Keen, M. J., Ross, D. I., and Lack, M.: Baffin bay: Small ocean basin formed by sea-floor spreading, Am. Assoc. Petrol. Geol. Bull., 58, 1089-1108, 1974.

Keen, C., Potter, P., and Srivastava, S.: Deep seismic reflection data across the conjugate margins of the labrador sea, Can. J. Earth Sci., 31, 192-205, 1994.

Keen, C. E., Dickie, K., and Dehler, S. A.: The volcanic margins of the northern labrador sea: Insights to the rifting process, Tectonics, 31, TC1011, doi:10.1029/2011TC002985, 2012.

Kimbell, G. S., Gatliff, R. W., Ritchie, J. D., Walker, A. S. D., and Williamson, J. P.: Regional three-dimensional gravity modelling of the ne atlantic margin, Basin Res., 16, 259-278, doi:10.1111/J.1365-2117.2004.00232.X, 2004.

Kuzsnir, N.: South australia-antarctica conjugate rifted margins: Mapping crustal thickness and lithosphere thinning using satellite gravity inversion, 2009.

Lawver, L. A. and Müller, R. D.: Iceland hotspot track, Geology, 22, 311-314, 1994.

Louden, K. E., Tucholke, B. E., and Oakey, G. N.: Regional anomalies of sediment thickness, basement depth and isostatic crustal thickness in the north atlantic ocean, Earth Planet Sc. Lett. 224, 193-211, 2004.

Lundin, E. R. and Dore, A. G.: Hyperextension, serpentinization, and weakening: A new paradigm for rifted margin compressional deformation, Geology, 39, 347-350, 2011.
McKenzie, D.: Some remarks on the development of sedimentary basins, Earth Planet Sc. Lett., 40, 25-32, 1978.

Müller, R. D., Sdrolias, M., Gaina, C., and Roest, W. R.: Age, spreading rates and spreading asymmetry of the world's ocean crust, Geochem. Geophys. Geosyst., 9, Q04006, doi:10.1029/2007GC001743, 2008.

Jackson, H. R. and Reid, I.: Crustal thickness variations between the greenland and ellesmere island margins determined from seismic refraction, Can. J. Earth Sci., 31, 1407-1418, 1994.

Oakey, G. N.: Cenozoic evolution and lithosphere dynamics of the baffin bay-nares strait region of arctic canada and greenland, 233 pp., Unpublished Ph. D. thesis, Vrije Universiteit, Amsterdam, The Netherlands, 2005.

Oakey, G. N. and Chalmers, J. A.: A new model for the paleogene motion of greenland relative to north america: Plate reconstructions of the davis strait and nares strait regions between canada and greenland, J. Geophys. Res.-Sol. Ea., 117, B10401, doi:10.1029/2011JB008942, 2012.

Oakey, G. N. and Stephenson, R.: Crustal structure of the innuitian region of arctic canada and greenland from gravity modelling: Implications for the palaeogene eurekan orogen, Geophys. J. Int., 173, 1039-1063, 2008.

Okulitch, A., Dawes, P., Higgins, A., Soper, N., and Christie, R.: Towards a nares strait solution: Structural studies on southeastern ellesmere island and northwestern greenland, Mar. Geol., 93, 369-384, 1990.

Parker, R. L.: The rapid calculation of potential anomalies, Geophys. J. Roy. Astr. S., 31, 447-455, 1972.

Ramesh, D., Kind, R., and Yuan, X.: Receiver function analysis of the north american crust and upper mantle, Geophys. J. Int., 150, 91-108, 2002.

Reid, I. and Jackson, H. R.: Crustal structure of northern baffin bay: Seismic refraction results and tectonic implications, J. Geophys. Res.-Sol. Ea., 102, 523-542, 1997.

Roest, W. R. and Srivastava, S. P.: Seafloor spreading in the labrador sea: A new reconstruction, Geology, 17, 1000-1004, 1989.

Rowley, D. B. and Lottes, A. L.: Plate-kinematic reconstructions of the north atlantic and arctic: Late jurassic to present, Tectonophysics, 155, 73-120, 1988 .

Sandwell, D. T. and Smith, W. H. F.: Global marine gravity from retracked geosat and ers-1 altimetry: Ridge segmentation versus spreading rate, J. Geophys. Res., 114, B01411, doi:10.1029/2008JB006008, 2009.

Sawyer, D. S.: Total tectonic subsidence: A parameter for distinguishing crust type at the U.S. Atlantic continental margin, J. Geophys Res., 90, 7751-7769, 1985.

Seton, M., Müller, R., Zahirovic, S., Gaina, C., Torsvik, T., Shephard, G., Talsma, A., Gurnis, M., Turner, M., and Chandler, M. Global continental and ocean basin reconstructions since $200 \mathrm{ma}$ Earth Sci. Rev., 113, 212-270, 2012.

Skaarup, N., Jackson, H. R., and Oakey, G.: Margin segmentation of baffin bay/davis strait, eastern canada based on seismic reflection and potential field data, Mar. Petrol. Geol., 23, 127-144, 2006.

Srivastava, S. P.: Davis strait: Structures, origin and evolution, in: Structure and development of the greenland-scotland ridge, edited by: Bott, M. H. P., Saxov, S., Talwani, M., and Thiede, J., Plenum, 159-189, 1983.

Srivastava, S. P. and Falconer, R. K.: Nares strait: A conflict between plate tectonic predictions and geological interpretation, in: 
Nares Strait and the drift of Greenland: a conflict in plate tectonics, edited by: Dawes, P. R. and Kerr, J. W., Meddelelser om Grønland, Geoscience, 8, 339-352, 1982.

Srivastava, S. P. and Roest, W. R.: Extent of oceanic crust in the labrador sea, Mar. Petrol. Geol., 16, 65-84, 1999.

St-Onge, M. R., Van Gool, J. A., Garde, A. A., and Scott, D. J.: Correlation of archaean and palaeoproterozoic units between northeastern canada and western greenland: Constraining the precollisional upper plate accretionary history of the trans-hudson orogen, Geol. Soc. Lond. Spec. Publ., 318, 193-235, 2009.

Storey, M., Duncan, R. A., Pedersen, A. K., Larsen, L. M., and Larsen, H. C.: Ar-40/ar-39 geochronology of the west greenland tertiary volcanic province, Earth Planet Sc. Lett. 160, 569-586, 1998.

Suckro, S. K., Gohl, K., Funck, T., Heyde, I., Ehrhardt, A., Schreckenberger, B., Gerlings, J., Damm, V., and Jokat, W.: The crustal structure of southern baffin bay: Implications from a seismic refraction experiment, Geophys. J. Int., 190, 37-58, 2012.

Suckro, S. K., Gohl, K., Funck, T., Heyde, I., Schreckenberger, B., Gerlings, J., and Damm, V.: The davis strait crust - a transform margin between two oceanic basins, Geophys. J. Int., 193, 78-97, 2013.
Torsvik, T. H., Muller, R. D., Van der Voo, R., Steinberger, B., and Gaina, C.: Global plate motion frames: Toward a unified model, Rev. Geophys., 46, RG3004, doi:10.1029/2007RG000227, 2008.

Whittaker, R. C., Hamann, N. E., and Pulvertaft, T.: A new frontier province offshore northwest greenland: Structure, basin development, and petroleum potential of the melville bay area, AAPG Bull., 81, 978-998, 1997.

Williams, S. E., Whittaker, J. M., and Müller, R. D.: Full-fit, palinspastic reconstruction of the conjugate australian-antarctic margins, Tectonics, 30, 1-21, 2011.

Wilson, R. W., Klint, K. E. S., van Gool, J. A., McCaffrey, K. J., Holdsworth, R. E., and Chalmers, J. A.: Faults and fractures in central west greenland: Onshore expression of continental breakup and sea-floor spreading in the labrador-baffin bay sea, GEUS Bull., 11, 185-204, 2006.

Winefield, P., Steffens, G., Bergman, S., Bishop, A., Wannier, M., Dimarco, M., van Oosterhout, C., Ross, M., and Hafkenscheid, E.: Ranking "white space" frontier regions-an arctic example illustrating the power of integrating plate tectonic reconstructions into regional evaluations, Offshore Technology Conference, 2011. 